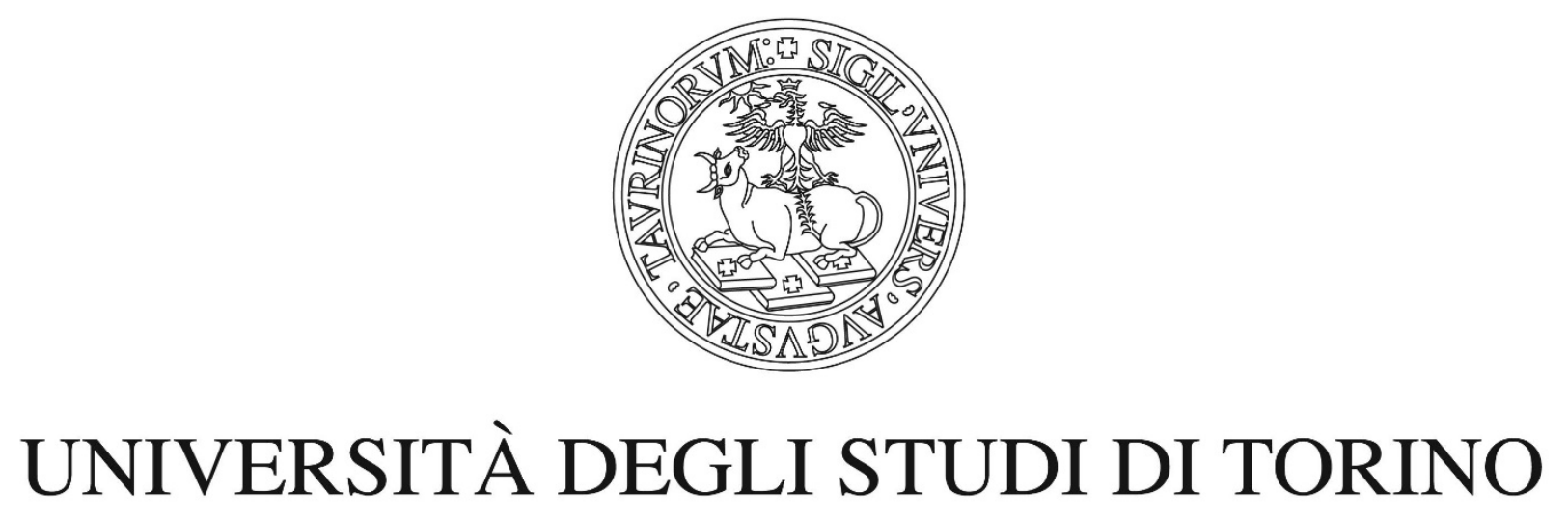

This is an author version of the contribution published on:

Questa è la versione dell'autore dell'opera:

Catoni M., D'Amico M.E., Zanini E., Bonifacio E. (2016). Effect of pedogenic processes and formation factors on organic matter stabilization in alpine forest soils.

Geoderma 263, 151-160. doi:10.1016/j.geoderma.2015.09.005

The definitive version is available at:

La versione definitiva è disponibile alla URL:

http://www.sciencedirect.com/science/article/pii/S0016706115300781 


\title{
Effect of pedogenic processes and formation factors on organic matter stabilization in alpine forest soils
}

Marcella Catoni*, Michele E. D’Amico, Ermanno Zanini, Eleonora Bonifacio

Department of Agricultural, Forest and Food Sciences (DISAFA), University of Torino, Largo Paolo Braccini 2,10095 Grugliasco, Italy.

*Corresponding author: e-mail: marcella.catoni@unito.it, Tel: (+39) 0116708522, Fax: (+39) 0116708692.

\begin{abstract}
Understanding the mechanisms involved in the building up of organic matter pools with long residence time in soils is fundamental for the comprehension of carbon dynamics. As organic matter persistence depends on environmental conditions and soil properties, both pedogenic processes and factors should be key elements for identifying the link between organic pools and stabilization mechanisms.

In the Ligurian Alps, an area where pedodiversity is large, we evaluated the importance of two soil formation factors, vegetation and parent material, and consequently pedogenic processes and soil features, on organic matter stabilization in forest soils. We thus selected 20 profiles, developed on different parent materials and forest stands, which ranged from Regosols, to Cambisols, to Chernozems/Kastonozems, to Podzols and Luvisols/Alisols. In the mineral horizons, we determined the soil physico-chemical properties and fractionated organic matter into labile and stabilized (recalcitrant and mineral-bound) pools using $\mathrm{NaClO}$ followed by HF treatment.

Soil and organic matter characteristics were primarily explained by the parent material and soil type, while vegetation affected organic matter quality but not the total amounts. The labile and recalcitrant organic pool proportions were linked to parent material likely through its effect on $\mathrm{pH}$ and other microenvironment characteristics. The mineral-associated organic matter instead followed a pedogenic pathway, with higher percentages of stable organic carbon in illuvial B horizons from Podzols and Luvisols/Alisols. In the study area, therefore, the most developed soils were relatively more resilient for organic matter conservation than less developed soils, which are more prone to C losses.
\end{abstract}

Keywords: sodium hypochlorite, hydrofluoric acid, organic matter fractionation, mineral horizons, C sequestration. 


\section{Introduction}

Soil organic matter $(\mathrm{OM})$ represents one of the most important carbon $(\mathrm{C})$ reservoirs in the global $\mathrm{C}$ cycle (Lal, 2008) also thanks to the slow turnover of some protected OM fractions. Indeed, if a portion of OM, called labile OM pool, is quickly decomposed and its structural C released, a stable OM pool may persist in the soils from decades to millennia (Schmidt et al., 2011). Soil OM stabilization principally consists in the intrinsic recalcitrance of organic compounds to degradation and in the interaction with mineral phases, such as the inclusion of organic components into aggregates and the formation of chemical bonds between OM and mineral surfaces (Sollins et al., 1996; von Lützow et al., 2006; Jastrow et al., 2007). The complexity of the chemical structure of organic molecules has been used to explain OM persistence for long times (Stevenson, 1994), but the importance of recalcitrance as a fundamental mechanism of OM stabilization has been recently questioned (e.g. Marschner et al., 2008). The stabilization of OM by association with minerals is instead acknowledged by many authors as the main reason of OM persistence (e.g. Torn et al., 1997), and this mechanism accounts for the long residence time of even chemically labile and quickly decomposable organic compounds, such as sugars (Schmidt et al., 2011). All these mechanisms operate simultaneously, although their relative importance may differ depending on specific environmental conditions and soil features, which in turn are related to the factors of soil formation and to pedogenic processes (Jenny, 1994; Schmidt et al., 2011).

Vegetation is among the pedogenic factors that primarily influence soil OM in terms of both quantity and quality. Leaf and root litter from different forest species largely differs in the amount of lignin, tannins, waxes and other recalcitrant compounds; therefore, the molecular structure and chemical composition of organic materials predominate in driving the first steps of decomposition and contribute in controlling the long-term persistence of OM (Schmidt et al., 2011). Besides, biochemical recalcitrance may also arise because of unsuitable conditions for decomposers, such as low $\mathrm{N}$ contents in fresh litter (Melillo et al. 1982) or the lack of macronutrients and necessary co-metabolites (Schmidt et al. 2011), which limit OM decomposition rate. On the other hand, parent material sharply affects the characteristics of the soil mineral phase, thus it is expected to influence the extent of OM stabilization by organo-mineral associations. The association between $\mathrm{OM}$ and minerals occurs thanks to the formation of chemical bonds through ligand 
exchange, cation bridges or weaker Van der Waals interactions, depending on soil mineralogical composition. In the last years, several adsorption experiments performed under controlled conditions (e.g. Gu et al., 1994) showed that ligand exchange between hydroxyl (-OH) groups on mineral surfaces and carboxyl groups $(-\mathrm{COOH})$ or phenolic $-\mathrm{OH}$ groups of $\mathrm{OM}$ is the preferential mechanism for the formation of stable organo-mineral associations. Hence, this mechanism is expected to act mainly in well-developed soils or where $\mathrm{Fe}$ and $\mathrm{Al}$ (hydr)oxides form a considerable part of the soil inorganic phase (e.g. Kleber et al., 2005). Conversely, in the presence of low CEC minerals, such as lithogenic micas, Van der Waals interactions may account for about 50\% of bound-OM (Mikutta et al., 2007). The role of parent material on OM stabilization may also be less specific and related to the effect it has directly on soil properties, such as $\mathrm{pH}$ and texture, or indirectly on microfauna activity and microbial biomass (e.g. Anderson, 1988, Heckman et al., 2009, Littke et al., 2011).

Mountain forest soils are often poorly developed due to slope steepness, erosion and other disturbance factors (Legros, 1992). Consequently, the influence of the parent material on soil properties is often remarkable, affecting soil $\mathrm{pH}$, texture and mineralogical composition (D'Amico et al., 2014a). On the other hand, the presence of elevation belts shapes the occurrence of forest vegetation types and contributes in affecting soil development and differentiating soil properties (D'Amico et al., 2014b). In an alpine context, in fact, plant communities represent a good indication of the climatic conditions, since they are especially sensitive to soil temperatures and well differentiated along elevation (Giordano, 2013). The southernmost part of the Alpine arc is characterized by a wide range of forest types, which, depending on elevation, range from broadleaved and pine trees of the montane belt to larches and grasslands of the subalpine area. In this geographic area, lithological variability is also large, and vegetation and parent material seem to represent two among the most variable factors affecting soil development; they are thus possibly linked to the large pedodiversity characterizing the site. In this area, we fractionated soil OM into labile, recalcitrant and mineral-associated pools using an oxidative degradation treatment with $\mathrm{NaClO}$ followed by mineral dissolution with HF. We hypothesized that the amount and proportion of the OM pools could be affected by soil development and the above mentioned pedogenic factors. The aims of this work were therefore i) to evaluate the relative importance of forest cover and parent material, and consequently of pedogenic processes, on OM stabilization in alpine forest soils; and ii) to verify if soils belonging to different soil 
groups, and therefore differing in physico-chemical characteristics, showed specific OM stabilization patterns.

\section{Materials and methods}

\subsection{Study area and soils}

The study area is located in the Ligurian Alps at the border between the Piemonte and Liguria regions, North-Western Italy (Figure 1). Based on a much larger number of observations, twenty sites were selected, which represented the most common combinations of forest cover and lithology of the soil parent material (Table 1). Seven sites were identified under beech stands (FS, Fagus sylvatica L.), which cover around 30\% of the total forest surface, and are the most represented forest type in the considered area (Regione Liguria, 2012; Regione Piemonte, 2012). Other widespread forest stands in the area are chestnut (CS, Castanea sativa Mill.; 5 sites), Scots or bog pines (PS, Pinus sylvestris L. or Pinus montana Miller; 4 sites), and hornbeamash associations (FO, Fraxinus ornus L. and Ostrya carpinifolia Scop.; 2 sites), covering approximately 10$15 \%$ of forest surface each. Larch stands, often associated with grasslands (LD, Larix decidua Mill.; 2 sites) occupy around $8 \%$ of the area. From the geological point of view, all sites are located on either the Ligurian Briançonnais domain or the Helminthoides Flysch units, and on their colluvial deposits (ISPRA, 2004). Specifically, the soils selected on the Ligurian Briançonnais domain developed on strata composed by quartzite or metamorphic porphiroids (QTZ; 6sites) or limestone-dolostone (LIM; 5 sites), while the soil parent material of the sites on the Helminthoides Flysch units (FLY; 9 sites) is formed by both calcareous and non-calcareous weakly metamorphosed siltstones and claystones discontinuously interbedded by sandstones.

The selected sites ranged in elevation from 840 to $1700 \mathrm{~m}$ a.s.l. (Table 1), which corresponds to the montane and lower subalpine phytoclimatic level. The FO sites were located at the lowest elevation (on average 852 $\mathrm{m}$ asl), the elevation of the sites covered by CS (990 m), FS (1250 m) and PS (1280 m) did not significantly differ and the CS did not differ either from FO. The LD sites were at the highest altitudes (1650 m a.s.l., on average). The area is characterized by two soil temperature regimes depending on elevation: the sites below $1300 \mathrm{~m}$ a.s.l. have a mesic regime while those at higher elevation are cryic. The soil moisture regime is udic at all sites (Cagnazzi and Marchisio, 1998). 
In each site, a representative soil profile was opened and all the morphological horizons were described. After removing the organic layers, the horizons were sampled from the profile pit walls and the material was collected from the whole depth of the morphological horizons, with a total of seventy-nine samples (Table 1). The selected soils were generally thinner than $1 \mathrm{~m}$ and showed a varying degree of evolution. According to the WRB soil classification system (IUSS Working Group WRB, 2014), most profiles belonged to the Regosol and Cambisol Groups. In addition, some specific diagnostic horizons occurred. On calcareous parent materials with little leaching of basic components, the soils showed humus-rich mollic epipedons and thus were included in the Kastanozem or Chernozem Groups (P4 and 6, respectively). Albic and both cemented and non-cemented spodic horizons were instead recognized in soil developed on acid rocks, such as quartzite and/or meta-porphiroids, and in presence of moderate slopes $(<50 \%)$. Independently from the type of parent material, argic horizons were also identified in the field thanks to the formation of clay cutans on the aggregate faces, although the horizon sequence was sometimes disturbed by natural or anthropogenic soil covers (Colluvic, Escalic and Transportic qualifiers; Table 1).

\subsection{Soil physico-chemical analyses}

The mineral soil samples were air-dried and sieved to $2 \mathrm{~mm}$ before chemical analyses. The $\mathrm{pH}$ was determined potentiometrically in a 1:2.5 soil:deionised water suspension (Van Reeuwijk, 2002), the C and N contents were determined through dry combustion (CE Instruments NA2100 elemental analyser, Rodano, Italy). The content of inorganic $\mathrm{C}$ was measured with the TIC-solid module of a TOC analyser (Vario TOC Elementar, Hanau, Germany) and the amounts were subtracted from the total $\mathrm{C}$ to obtain organic $\mathrm{C}$ ( $\left.\mathrm{OC}_{\mathrm{UT}}\right)$. The particle size distribution was evaluated by the pipette method after $\mathrm{H}_{2} \mathrm{O}_{2}$ treatment and dispersion of the sample with Na-hexametaphosphate (Gee and Bauder, 1986). Iron was extracted using dithionite-citratebicarbonate ( $\mathrm{Fe}_{\mathrm{D}}$, Mehra and Jackson, 1960) and acid ammonium oxalate (Fe, Schwertmann, 1964) solutions, and the concentrations were determined by atomic absorption spectrophotometry (Perkin Elmer Analyst 400, Waltham, MA, USA) in both extracts. All analyses were duplicated. 


\subsection{Organic matter fractionation}

The samples were chemically treated following the procedure described by Mikutta et al. (2006). The samples were oxidized 3 times with $6 \% \mathrm{NaClO}$ at $\mathrm{pH}$, with a ratio soil:solution 1:10. They were then washed with deionized water until the electrical conductivity was below $40 \mu \mathrm{S} \mathrm{cm}^{-1}$, oven-dried at $40^{\circ} \mathrm{C}$ and the OC concentrations were determined as described above. The oxidized samples were treated successively with $10 \% \mathrm{HF}$ to remove the mineral phase, washed and dried. The $\mathrm{C}$ concentrations were again determined and assumed to represent the $\mathrm{OM}$ pool which is stabilized by chemically recalcitrance $\left(\mathrm{OC}_{\mathrm{rec}}\right)$. The $\mathrm{NaClO}-$ labile pool $\left(\mathrm{OC}_{\mathrm{lab}}\right)$ was calculated as the difference between the initial $\mathrm{OC}_{\mathrm{UT}}$ content and that remaining in the sample after oxidation, while the amount of organic $\mathrm{C}$ stabilized by interaction with the mineral phase $\left(\mathrm{OC}_{\text {min }}\right)$ was calculated as the difference between $\mathrm{NaClO}$ resistant-OC and $\mathrm{OC}_{\text {rec. }}$. Some inherently stable $\mathrm{C}$ compounds can however also be stabilized by association with the mineral phase. Thus, in this type of fractionation, $\mathrm{OC}_{\mathrm{rec}}$ is the fraction that is stabilized by chemical recalcitrance only, while $\mathrm{OC}_{\min }$ is a fraction that may comprehend either chemically stable components or more labile fractions, which are however released upon the dissolution of minerals.

All analyses were duplicated and the data were corrected for weight loss during the treatments.

\subsection{Statistical analyses}

Statistical analysis was carried out using IBM-SPSS Statistics 21, splitting the dataset by master soil horizons (i.e. A, B, C). When transition horizons were present, the dominant characteristics were used (e.g. $\mathrm{AB}$ recoded into A type; $\mathrm{CA}$ recoded into $\mathrm{C}$ type). Albic horizons (E) were excluded from the analyses as only one case was present in the dataset after recoding.

To verify that the effect of climatic variations on soil types and OC concentrations was effectively encompassed by using forest types as independent variables some preliminary tests were carried out and the results reported in the electronic annex. No significant correlations were found between elevation and OC concentrations (Table A1, electronic annex) nor were soil types located at significantly different elevations (Table A2, electronic annex). For all horizons, the OC concentration did not differ between the north-facing and the south-facing soils ( $P>0.05$, always) and the distribution of soil types was not significantly affected either $\left(\chi^{2} P=0.367\right)$. Similarly, we verified the effect of slope steepness on OC and soil type distribution. The 
OC concentrations were not correlated to slope steepness (Table A1, electronic annex), with the exception of a positive correlation in $\mathrm{C}$ horizons we could not explain. In addition, although Regosols were globally characterized by steeper slopes (Table A2, electronic annex), the differences between soil types were not significant. The results of these preliminary tests suggested therefore that relief was not among the dominant pedogenic factors shaping pedodiversity in the study area and that the effect of climate was indirectly taken into account when evaluating the effect of vegetation.

The differences in soil properties were evaluated by analysis of variance (General Linear Model), using lithology and dominant forest cover as independent variables, and then through a one-way ANOVA by soil type. For this purpose, soil classification was recoded using the occurrence of diagnostic horizons as follows: 1) no diagnostic horizons (i.e. Regosols); 2) cambic horizons (i.e Cambisols); 3) mollic horizons (i.e. Chernozems and Kastanozems); 4) argic horizons (Luvisols and Alisols); 5) spodic horizons (Podzols). Before performing the ANOVA, Levene's test for equality of variances was performed and the data checked for normality using the Shapiro-Wilk test. When these assumptions were not met, the variables were mathematically transformed. Differences among groups were evaluated with the Duncan's test. The correlation between variables was evaluated using the Pearson's coefficient (two-tailed), after a visual inspection of the data to verify that the dependence relationship was linear. A threshold of 0.05 was always used for significance.

\section{Results}

\subsection{Soil physical and chemical properties}

The $\mathrm{OC}_{\mathrm{UT}}$ contents were highly variable in the A and B horizons, while they were more homogeneous in the $\mathrm{C}$ ones (Table 2). Nevertheless, forest cover did not affect the concentrations in A and C horizons, while a significant effect of both vegetation and parent material was found in B ones (Table 3). The B horizons of the soils of FO forest stands developed on LIM showed much higher contents of $\mathrm{OC}_{\mathrm{UT}}$ (Table 2) in comparison to those occurring on the other sites. Soil type influenced the quantity of $\mathrm{OC}_{\mathrm{UT}}$ in $\mathrm{B}$ horizons as well, with those of Chernozems/Kastanozems much higher than those of all other soils (Table 2).

The quality of $\mathrm{OM}$, evaluated as $\mathrm{C}_{\mathrm{UT}} / \mathrm{N}$ ratio, was affected by vegetation in the $\mathrm{A}$ horizons, while in $\mathrm{C}$ and $\mathrm{B}$ ones a significant effect of lithology was found; in $\mathrm{C}$ horizons an interaction effect was present as well 
(Table 3). Soils developed on QTZ had higher $\mathrm{C}_{\mathrm{UT}} / \mathrm{N}$ ratios than those sampled on the other lithologies, while in general the PS stands showed higher values in comparison to the other forest stands (Table 2). Also soil type significantly contributed in differentiating the ratios: Podzols had the highest $\mathrm{C}_{\mathrm{UT}} / \mathrm{N}$ ratio in A horizons and Regosols the lowest (Table 2), although not different from soils with mollic epipedons. These differences were maintained in B horizons and disappeared in $\mathrm{C}$ ones (Table 3).

The parent material was the main factor of $\mathrm{pH}$ variation in all horizons, while forest cover showed an effect only in B ones; similar results were obtained for particle size distribution (Table 3). As expected, also the effect of soil type was significant, as $\mathrm{pH}$ increased in the order Podzols $<$ Cambisols-Luvisols/AlisolsRegosols < Chernozems/Kastanozems in A horizons (Table 2), while in B horizons only soils with mollic epipedons were still different from the others. Podzols were sandier than all other soils in A and B horizons, while the argic B horizons were the clay-richest, although not different from those of Cambisols and Chernozems/Kastanozems.

Differences in total $\mathrm{Fe}$ oxides $\left(\mathrm{Fe}_{\mathrm{D}}\right)$ were also visible, and related to parent material only (Table 3). In all horizons, the lowest contents were found in the samples on QTZ (Table 2). The amounts of $\mathrm{Fe}_{\mathrm{D}}$ varied with soil type with B horizons of Luvisols/Alisols and Chernozems/Kastanozems having the maximum concentrations. The poorly crystalline oxides $\left(\mathrm{Fe}_{\mathrm{O}}\right)$ significantly differed according to forest cover in A horizons, which were however affected also by lithology (Table 3). The Feo-richest ones were the A horizons of soils developed on FLY, particularly under LD or CS cover. A significant effect of soil type was visible as well (Table 3), with the A horizons of Podzols having the lowest contents and those of Regosols the highest (Table 2). Although not significantly different from those of the other soil groups, the B horizons of Podzols and of Luvisols/Alisols were the most $\mathrm{Fe}_{\mathrm{O}}$-enriched.

\subsection{Organic matter fractionation}

The chemical oxidation with $6 \% \mathrm{NaClO}$ (Table 4) removed rather large amounts of OC, ranging from 3 to $113 \mathrm{~g} \mathrm{~kg}^{-1}$. The labile fraction $\left(\mathrm{OC}_{\mathrm{lab}}\right)$ was related to the amounts of $\mathrm{OM}$ present in the soil (Figure $2 \mathrm{a} ; \mathrm{n}=79$, $\mathrm{r}=0.997, P<0.001)$, and formed on average $82 \pm 7 \%$ of $\mathrm{OC}_{\mathrm{UT}}$. The proportion of $\mathrm{OC}_{\text {lab }}\left(\% \mathrm{OC}_{\mathrm{UT}}\right)$ showed no

effect of forest cover in A and C horizons, although in B horizons, in addition to the effect of lithology, a significant interaction effect was found (Table 5). Lower proportions of $\mathrm{OC}_{\text {lab }}$ were found in $\mathrm{B}$ horizons of 
soils on QTZ, particularly under PS (Table 4). In B horizons, a significant effect of soil type on the labile OC $\left(\% \mathrm{OC}_{\mathrm{UT}}\right)$ was also present (Table 5), with the smallest proportion in those of Podzols $\left(69.5 \pm 4.6 \% \mathrm{OC}_{\mathrm{UT}}\right)$ and the largest in the B of Chernozems/Kastanozems $\left(93.9 \pm 2.5 \% \mathrm{OC}_{\mathrm{UT}}\right)$ (Figure 3a).

The amounts of $\mathrm{OC}_{\mathrm{rec}}$ ranged from 0.1 to $12.8 \mathrm{~g} \mathrm{~kg}^{-1}$ and were still dependent on the original amounts of $\mathrm{OC}_{\mathrm{UT}}$ (Figure 2b), but the correlation coefficient was slightly lower $(\mathrm{n}=79, \mathrm{r}=0.881, P<0.001)$. On average $\mathrm{OC}_{\text {rec }}$ represented $10 \pm 5 \%$ of $\mathrm{OC}_{\mathrm{UT}}$, and the proportion showed significant differences only with lithology, and only in A and C horizons (Table 5). The soils on LIM had the lowest proportion and those on QTZ the highest (Table 4). No significant effect of soil development was found although a low proportion of $\mathrm{OC}_{\mathrm{rec}}$ was present in Chernozems/Kastanozems, in the $\mathrm{C}$ horizons of Cambisols and in the $\mathrm{B}$ horizons of Luvisols/Alisols (Figure 3b).

The amounts of $\mathrm{OC}$ released upon $\mathrm{HF}$ treatment $\left(\mathrm{OC}_{\min }\right)$ were on the average $1.3 \pm 1.2 \mathrm{~g} \mathrm{~kg}^{-1}$, representing about $7.4 \%$ of $\mathrm{OC}_{\mathrm{UT}}$ with a very large variability (Table 4$)$. Along the profiles, the proportion of $\mathrm{OC}_{\min }(\%$ OC $_{\mathrm{UT}}$ ) was always higher in $\mathrm{B}$ horizons (on average $11.3 \pm 6.5 \%$ of $\mathrm{OC}_{\mathrm{UT}}$ ) than in $\mathrm{A}$ ones, with the exception of soils showing mollic epipedons. No relationship between $\mathrm{OC}_{\min }$ and $\mathrm{OC}_{\mathrm{UT}}$ was visible (Figure $2 \mathrm{c}$ ) and neither forest cover nor parent material affected the amount and proportion of $\mathrm{OC}_{\min }$ (Table 5). Differences in the proportion of $\mathrm{OC}_{\min }$ were instead observed in $\mathrm{B}$ horizons when soil type was taken into account (Figure 3c), with Podzols and Luvisols/Alisols (thus spodic and argic horizons, Bs and Bt) having a much higher content than the B horizons of Cambisols and Chernozems/Kastanozems (Bw and/or Bk).

\section{Discussion}

In this work, we wanted to assess the effect of vegetation and parent material and of pedogenic processes on OM stabilization. After preliminary tests, we assumed that climatic variations in the area were implicitly taken into account due to the presence of clear vegetation belts, while slope steepness and other geomorphic characteristics did not significantly affect the OC concentrations. Hence, we evaluated the relative importance of forest cover and lithology on soil characteristics and on the amounts and proportions of OM pools, and verified if soils that belonged to different taxonomic groups, which thus differed in physicochemical characteristics, showed varying OM stabilization patterns. 
In general, lithology was the main pedogenic factor linked to the variations in OM quantity and quality (Table 3), while forest cover seemed to be less determinant. The amounts of $\mathrm{OC}_{\mathrm{UT}}$ in topsoils in fact did not vary with forest stands, but the vegetation factor significantly affected the $\mathrm{C}_{\mathrm{UT}} / \mathrm{N}$ ratio (Table 3 ). Binkley (1995) observed that the amounts of OM depended on vegetation but, contrary to our study, the forest soils experimental plots had homogeneous site conditions. Previous studies in fact showed that in mountain situations characterized by a large short-scale variability in the expression of soil formation factors, OM contents were not even related to the broad distinction between grasslands and forests, although the $\mathrm{C} / \mathrm{N}$ ratio reflected the origin of OM (e.g. Oueslati et al., 2013). This is therefore in agreement with the results obtained in this study where, in addition to the topography variability expected in mountain environments, a broad range in forest canopy, from 20 to $100 \%$ of vegetation cover (Table 1), could add to the variability. The samples collected under PS stands showed the highest $\mathrm{C}_{\mathrm{UT}} / \mathrm{N}$ values (Table 2), likely because of the composition of the litter from conifers, which is formed by more hydrophobic aromatic compounds (e.g. Dilling and Kaiser 2002), and the consequent lower degradability of OM (e.g. Moro and Domingo, 2000). The past management of LD stands as pastures, typical of the northern Italian mountain areas, had also a determinant effect on $\mathrm{OM}$ chemical composition and was likely the responsible of the low $\mathrm{C}_{\mathrm{UT}} / \mathrm{N}$ under larch. As already observed in other alpine sites (Scalenghe et al., 2002), the abundance of the herbaceous layers accounts for the rather low $\mathrm{C} / \mathrm{N}$ value, and organic matter quality appeared more related to the presence of grasses than to conifers.

The effect of parent material on the variations in soil properties, such as texture, amounts of pedogenic $\mathrm{Fe}$ (hydr)oxides and pH (Table 3), was well visible in almost all horizons. Soils on LIM had abundant clay and a significantly higher $\mathrm{pH}$ than soils developed on other parent materials, but also had greater $\mathrm{OC}_{\mathrm{UT}}$ contents. While the abundance of clay is expected to be directly related to the mechanisms of $\mathrm{OM}$ stabilization, $\mathrm{pH}$ likely influences OC contents indirectly, though the effect it exerts on soil biota. At neutral or slightly basic $\mathrm{pH}$ values, earthworms decrease OM mineralization by mixing A horizons with OC-poorer $\mathrm{B}$ ones and enhance OM incorporation into the mineral soil (Reich et al., 2005; Marhan and Scheu, 2006). Soil type affected the variability of all soil properties in most horizons, although in $\mathrm{C}$ ones soil characteristics were, as expected, only related to lithology. However, even in A and B horizons, the effect of soil processes mostly 
reflected that of the parent material with e.g. higher $\mathrm{pH}$ and $\mathrm{OC}_{\mathrm{UT}}$ contents in soils with mollic epipedons which develop on calcareous rocks, or the sandier texture of podzolic B horizons.

Although the samples were taken under different forest species and parent material types, the effect of both factors on the amounts of $\mathrm{OC}$ released upon $\mathrm{NaClO}$ oxidation $\left(\mathrm{OC}_{\mathrm{lab}}\right)$ was significant only in the $\mathrm{B}$ horizon, where the effect of soil type was also present (Table 5). This result was most likely caused by the strong dependence between $\mathrm{OC}_{\mathrm{lab}}$ and $\mathrm{OC}_{\mathrm{UT}}$ (Figure 2a), in agreement with several other works (e.g. Catoni et al., 2014; Thomsen et al., 2009). A similar significant correlation was found between $\mathrm{OC}_{\mathrm{rec}}$ and $\mathrm{OC}$ UT content, although with a relatively lower correlation coefficient (Figure 2b). Despite the OM fractions obtained through chemical oxidation do not perfectly reflect OM biodegradability in field conditions (Mikutta and Kaiser, 2011), phenols and lignin monomers are less sensitive to $6 \% \mathrm{NaClO}$ treatment than sterols and lipids (Sleutel et al., 2009). Consequently, we expected that OM quality, evaluated as relative $\mathrm{C}$ and $\mathrm{N}$ contents, was important in driving the proportion of $\mathrm{OC}_{\mathrm{rec}}$ and $\mathrm{OC}_{\text {lab. }}$. In fact, the $\mathrm{C} / \mathrm{N}$ ratio is often taken as index of OM quality and was found to be related to the sensitivity to oxidation treatments (Falsone et al., 2014). In spite of this, our results showed that the relationships between $\mathrm{C}_{\mathrm{UT}} / \mathrm{N}$ ratios and the proportions of $\mathrm{OC}_{\mathrm{lab}}$ $(\mathrm{n}=79, \mathrm{r}=-0.305, P<0.01)$ and $\mathrm{OC}_{\mathrm{rec}}(\mathrm{n}=79, \mathrm{r}=0.366, P<0.01)$ were rather poor, as the determination coefficients explained only 9 and $13 \%$ of sample variability, respectively. The large variability of the study area is likely to be responsible of this result, as the same $\mathrm{C}_{\mathrm{UT}} / \mathrm{N}$ ratio in different profiles may correspond to a completely diverse degree of transformation of OM. For example, the same $\mathrm{C}_{\mathrm{UT}} / \mathrm{N}$ ratio of 16 found in the $\mathrm{C}$ horizons of PS on limestones, was measured also in an A horizons of FS and in a B horizons of CS.

Recent works have highlighted that OM chemical composition is important only at the very first stages of the decomposition processes, and have firmly stated that the persistence of OM in soils is an ecosystem property, being thus affected by the surrounding environment (Schmidt et al., 2011). A better correlation was indeed found between the proportion of $\mathrm{OC}_{\mathrm{lab}}$ and $\mathrm{pH}(\mathrm{r}=0.522, \mathrm{n}=79, P<0.001)$, and thus likely related to the effect of parent material. The $\mathrm{pH}$ value has a well-known effect on the soil fauna activity and on microbial community composition, as at acidic $\mathrm{pH}$ fungal growth is considerably promoted against the bacterial communities (Rousk et al. 2009), while earthworms are normally absent. While cellulose is readily degraded by both fungi and bacteria, the complete degradation of the more recalcitrant lignin is restricted to a selected group of fungi (Heim and Frey 2004). Indeed, likely because of differences in activity and abundance of 
microbial communities, a lower amount of $\mathrm{OC}_{\mathrm{rec}}$ was observed where $\mathrm{OM}$ decomposition was mainly fungidominated. Only the selective alteration of the more labile forms occurred instead at higher $\mathrm{pH}$, resulting in a larger portion of recalcitrant OM. Nevertheless, also in this case, the explained variance was rather low (27\%) indicating that single soil properties could not fully account for the sensitivity to oxidation of OM.

Although the physical and mineralogical soil properties should be the main drivers affecting the OM pool stabilized by interaction with mineral surfaces, neither parent material nor vegetation had any effect on $\mathrm{OC}_{\min }$. The amounts of $\mathrm{OC}_{\min }$ were not affected by the initial $\mathrm{OC}$ contents (Figure 2c), nor their proportions were significantly related to the $\mathrm{C}_{\mathrm{UT}} / \mathrm{N}$ ratio, but in the $\mathrm{B}$ horizons a clear and significant effect of soil type occurred (Table 5). Along a profile, the B horizons show the maximum expression of pedogenic processes and are characterised by high amounts of secondary minerals (Schaetzl and Anderson, 2005). Pedogenic minerals, such as Fe and $\mathrm{Al}$ (hydr)oxides and secondary layer silicates, are the most efficient mineral for OM stabilization (Mikutta et al., 2007). Although $\mathrm{OC}_{\min }$ represented only a small proportion of total OC (Figure 3), its proportion in B horizons of Podzol and Luvisol/Alisol soil groups was on the average twice as much as that of the other soil horizons (Figure 3c). Spodic (Bs) and argic (Bt) horizons are characterized by the enrichment of illuviated materials from the upper horizons. Specifically, the Bs horizons are dominated by illuvial poorly crystalline oxides as the result of the podzolization process itself, while the Bt horizons are generally enriched of illuvial clay minerals and relatively high amounts of crystalline iron oxides can occur. All oxide phases, although with differences in available surface as a function of crystalline degree, are characterized by large heat of adsorption and little desorbability of OM due to the formation of ligand exchange bonds between $\mathrm{OM}$ and metals (Gu et al., 1994). In agreement with the effectiveness of ligand exchange for OM stabilization and with the prevalence of this mechanism in acidic soils (Mikutta et al., 2007; Spielvogel et al., 2008), the absolute amounts of $\mathrm{OC}_{\min }$ in $\mathrm{B}$ horizons were correlated with the poorly crystalline $\mathrm{Fe}$ (hydr)oxides $(\mathrm{r}=0.451, \mathrm{p}<0.05, \mathrm{n}=26$, i.e. $20 \%$ of variance explained), which were indeed abundant both in the Bs and Bt. In the Bt horizons, the high contents of clay might contribute to the stabilization due to the formation of multivalent cation bridges between OM and negatively charged surfaces of phyllosilicates. However, no additional correlations were found between soil properties and $\mathrm{OC}_{\text {min. }}$. Consequently, the relatively large amounts of (hydr)oxides in Bs and Bt horizons was the single soil property related to OC stabilization, but the global combination and interaction of soil properties from pedogenic 
processes in Podzols and Luvisols might have promoted $\mathrm{OM}$ accumulation and preservation against decomposition.

Although the importance of pedosphere in the global C cycle is well-known, a good knowledge of both soil $\mathrm{OM}$ characteristics and the mechanisms behind the long-time retention of some OM pools is required for a correct ecosystem analysis. In fact, as soils show a huge array of features that may differently affect OM persistence, the identification of the link between the main mechanisms of OM stabilization and pedogenic processes could be useful for a priori interpretation of soil environmental significance.

In this work, we indeed showed the relevance of surrounding environment and more specifically of some physico-chemical soil properties governing the OM stabilization. Nevertheless, we also highlighted that in natural systems a single or few soil variables are not sufficient to fully explain the complexity of the stabilization processes. On the other hand, when we consider the result of pedogenesis, thus the soil type, we clearly found that the most developed soils showed the highest potential to stabilize OM on mineral surfaces.

\section{Conclusions}

In a highly variable alpine forested area, vegetation and parent material contributed to originate soils with sharply different chemical and physico-chemical properties. Due to the large variability of these two factors, in the study area soils ranged from Regosols, to Cambisols, to Chernozems and Kastonozems, to Podzols and Luvisols or Alisols.

Nevertheless, vegetation did not influence the total amounts of OM, nor the amounts of $\mathrm{C}$ in OM pools. The properties of $\mathrm{OM}$ and soils were instead more related to the soil parent material and to pedogenic processes as expressed by soil types. The proportions of the labile and recalcitrant OM pools were also affected by parent material, possibly through its effect on soil properties, such as $\mathrm{pH}$. The proportion of OM stabilized through association with minerals followed instead pedogenic pathways, with higher percentages in illuvial B horizons from Podzols and Luvisols/Alisols. The relationships between soil chemical properties and OM pools were however always rather poor, although significant, thus suggesting that soil type, by representing a combination of soil properties, may be a better indicator of OM stabilization pattern in complex situation than specific soil characteristics. The most developed soils of the study area (i.e. Podzols and Alisols/Luvisols) seem to be relatively resilient for OM conservation, while less developed soils are more 
prone to C losses. Consequently, soil types, as arising from pedogenic processes help in the comprehension of $\mathrm{C}$ dynamics in mountain forest soils and could thus be integrated in C-turnover models or taken into consideration for forest management.

\section{Acknowledgments}

This work was funded by the POR-FESR 2007/2013 program (Poli innovazione-Regione Piemonte). (186$153 \mathrm{C})$

\section{References}

Anderson, J.M., 1988. Spatiotemporal effects of invertebrates on soil processes. Biol. Fertil. Soils 6, 216227.

Binkley, D.,1995. The influence of tree species on forest soils: processes and patterns. In: Mead, D.J., Cornforth, I.S. (eds.) Proceeding of the Trees and Soil Workshop, Lincoln University 28 February-2 March 1994. Lincoln University Press, Canterbury, pp 1-33.

Cagnazzi, B., Marchisio, C., 1998. Atlante climatologico del Piemonte. In: Precipitazioni e Temperature, Collana di Studi Climatologici in Piemonte, CD produced by Regione Piemonte-Università di Torino, Torino.

Catoni, M., D’Amico, M.E., Mittelmeijer-Hazeleger, M.C., Rothenberg, G., Bonifacio, E., 2014. Micropore characteristics of organic matter pools in cemented and non-cemented podzolic horizons. Eur. J. Soil Sci. 65, 763-773.

D’Amico, M.E., Freppaz, M., Leonelli, G., Bonifacio, E., Zanini, E., 2014a. Early stages of soil development on serpentinite: the proglacial area of the Verra Grande Glacier, Western Italian Alps. J. Soils Sediments. doi: 10.1007/s11368-014-0893-5.

D'Amico, M.E., Freppaz, M., Filippa, G., Zanini, E., 2014b.Vegetation influence on soil formation rate in a proglacial chronosequence (Lys Glacier, NW Italian Alps). Catena 113, 122-137.

Dilling, J., Kaiser, K., 2002. Estimation of the hydrophobic fraction of dissolved organic matter in water samples using UV photometry. Water Res. 36, 5037-5044. 
Falsone, G., Wilson, C.A., Cloy, J.M., Graham, M.C., Bonifacio, E., 2014. Relating microfeatures of soil organic matter to C stabilisation: optical microscopy, SEM-EDS, abiotic oxidation. Biol. Fert. Soils 50, 623632.

Gee, G.W., Bauder, J.W., 1986. Particle-size analysis.In: Klute A(ed)Methods of soil analysis, Part 1, 2nd edn. Agronomy Monograph 9, Agronomy Society of America and Soil Science Society of America, Madison, Wisconsin.

Giordano, A., 2013. Vegetation and land use. In: Costantini, E.C., Dazzi, C., (Eds); The soils of Italy. Springer, pp 57-92.

Gu, B., Schmitt, J., Chen, Z., Liang, L., McCarthy, J.F., 1994. Adsorption and desorption of natural organic matter on iron oxide: mechanisms and models. Environ. Sci. Technol. 28, 38-46.

Heckman, K., Welty-Bernard, A., Rasmussen, C., Schwartz, E., 2009. Geologic controls of soil carbon cycling and microbial dynamics in temperate conifer forests. Chem. Geol. 267, 12-23.

Heim, A., Frey, B., 2004. Early stage litter decomposition rates for Swiss forests. Biogeochemistry 70, 301315.

ISPRA, 2004. Carta Geologica d'Italia alla scala 1:100.000. http://193.206.192.231/carta_geologica_italia/cartageologica.htm.

IUSS Working Group WRB, 2014. World Reference Base for Soil Resources 2014. International soil classification system for naming soils and creating legends for soil maps. World Soil Resources Reports No. 106. FAO, Rome.

Jastrow, J.D., Amonette, J.E., Bailey, V.L., 2007. Mechanisms controlling soil carbon turnover and their potential application for enhancing carbon sequestration. Climatic Change 80, 5-23.

Jenny, H., 1994. Factors of soil formation. A system of quantitative pedology. Dover Publications Inc., New York, NY.

Kleber, M., Mikutta, R., Torn, M.S., Jahn, R., 2005. Poorly crystalline mineral phases protect organic matter in acid subsoil horizons. Eur. J. Soil Sci. 56, 717-725.

Lal, R., 2008. Sequestration of atmospheric $\mathrm{CO}_{2}$ in global carbon pools. Energ. Environ. Sci. 1, 86-100.

Legros, J.P., 1992. Soils of alpine mountains. In: Martini IP, Chesworth W (eds.) Weathering, soils andpaleosols. Elsevier, Amsterdam, Netherlands, pp 155- 181. 
Littke, K.M., Harrison, R.B., Briggs, D.G., Grider, A.R., 2011. Understanding soil nutrients and characteristics in the Pacific Northwest through parent material origin and soil nutrient regimes. Can. J. Forest Res. 41, 2001-2008.

Marhan, S., Scheu, S., 2006. Mixing of different mineral soil layers by endogeic earthworms affects carbon and nitrogen mineralization. Biol. Fert. Soils 42, 308-314.

Marschner, B., Brodowski, S., Dreves, A., Gleixner, G., Gude, A., Grootes, P.M., et al., 2008. How relevant is recalcitrance for the stabilization of organic matter in soils? J. Plant Nutr. Soil Sci. 171, 91-110.

Melillo, J.M., Aber, J.D., Muratore, J.F., 1982. Nitrogen and lignin control of hardwood leaf litter decomposition dynamics. Ecology 63, 621-626.

Mehra, O.P., Jackson, M.L., 1960. Iron oxide removal from soils and clays by a dithionite-citrate system buffered with sodium bicarbonate. Clay Clay Miner. Proceedings of the 7th National Clays and Clay Minerals Conference on Oct. 20-23, 1958, Washington, DC.

Mikutta, R., Kleber, M., Torn, M.S., Jahn, R., 2006. tabilization of soil organic matter: association with minerals or chemical recalcitrance? Biogeochemistry 77, 25-56.

Mikutta, R., Mikutta, C., Kalbitz, K., Scheel, T., Kaiser, K., Jahn, R., 2007. Biodegradation of forest floor organic matter bound to minerals via different binding mechanisms. Geochim. Cosmochim. Ac. 71, 25692590.

Mikutta, R., Kaiser, K., 2011. Organic matter bound to mineral surfaces: Resistance to chemicaland biological oxidation. Soil Biol. Biochem. 43, 1738-1741.

Moro, M.J., Domingo, F., 2000. Litter decomposition in four woody species in a mediterranean climate: weight loss, N and P dynamics. Ann. Bot. 86, 1065-1071.

Oueslati, I., Allamano, P., Bonifacio, E., Claps, P., 2013.Vegetation and topographic control on spatial variability of soil organic carbon. Pedosphere 23, 48-58.

Regione Liguria, 2012. Carta d'uso del suolo 1:10000. http://www.regione.liguria.it.

Regione Piemonte, 2012. Carta forestale e altre coperture del territorio 1:10000. http://www.sistemapiemonte.it.

Reich, P.B., Oleksyn, J.,Modrzynski, J.,Mrozinski, P., Hobbie, S.E., Eissenstat, D.M., et al.,2005. Linking litter calcium, earthworms and soil properties: a common garden test with 14 tree species. Ecol. Lett. 8, 811818. 
Rousk, J., Brookes, P.C., Bååth, E., 2009. Contrasting soil pH effects on fungal and bacterial growth suggest functional redundancy in carbon mineralization. Appl. Environ. Microb. 75, 1589-1596.

Schaetzl, R., Anderson, S., 2005. Soils: genesis and geomorphology. Cambridge University Press, New York.

Scalenghe, R., Bonifacio, E., Celi, L., Ugolini, F.C., Zanini, E., 2002. Pedogenesis in disturbed alpine soils (NW Italy). Geoderma 109, 207-224.

Schmidt, M., Torn, M., Abiven, S., Dittmar, T., Guggenberger, G., Janssens, I., et al., 2011. Persistence of soil organic matter as an ecosystem property. Nature 478, 49-56.

Schwertmann, U. 1964. Differenzierung der Eisenoxide des Bodens durch Extraktion mit Ammoniumoxalatlösung. Zeitschrift für Pflanzenernhärung, Düngung und Bodenkunde 105, 194-201.

Sleutel, S., Leinweber, P., Begum, S.A., Kader,M.A., De Neve, S., 2009. Shifts in soil organic matter composition following treatment with sodium hypochlorite and hydrofluoric acid. Geoderma 149, 257-266.

Sollins, P., Homann, P., Caldwell, B.A., 1996. Stabilization and destabilization of soil organic matter: Mechanisms and controls. Geoderma 74, 65-105.

Spielvogel, S., Prietzel, J., Kögel-Knabner, I., 2008. Soil organic matter stabilization in acidic forest soils ispreferential and soil type-specific. Eur. J. Soil Sci. 59, 674-692.

Stevenson, F.J., 1994. Humus Chemistry. John Wiley \& Sons, New York.

Thomsen, I.K., Bruun, S., Jensen L.S., Christensen, B.T., 2009. Assessing soil carbon lability by near infrared spectroscopy and $\mathrm{NaOCl}$ oxidation. Soil Biol. Biochem. 41, 2170-2177.

Torn, M.S., Trumbore, S.E., Chadwick, O.A., Vitousek, P.M., Hendricks, D.M., 1997. Mineral control of soil organic carbon storage and turnover. Nature 389, 170-173.

van Reeuwijk, L.P., 2002. Procedures for Soil Analysis. Technical Paper n. 9. International Soil Reference and Information Centre. Wageningen, Netherlands.

von Lützow, M., Kögel-Knabner, I., Ekschmitt, K., Matzner, E., Guggenberger, G., Marschner, B. et al., 2006. Stabilization of organic matter in temperate soils: mechanisms and their relevance under different soil conditions - a review. Eur. J. Soil Sci. 57, 426-445. 
Table 1 - Site characteristics, horizon sequence and classification of studied soil profiles.

\begin{tabular}{|c|c|c|c|c|c|c|c|c|}
\hline $\begin{array}{l}\text { Pro } \\
\text { file }\end{array}$ & $\begin{array}{l}\text { Coordinates UTM } \\
\text { WGS84 (32T) }\end{array}$ & $\begin{array}{l}\text { Elevatio } \\
\mathrm{n}(\mathrm{m} \\
\text { a.s.l. })\end{array}$ & $\begin{array}{l}\text { Parent } \\
\text { material }^{\mathrm{a}}\end{array}$ & $\begin{array}{l}\text { Prevailin } \\
\mathrm{g} \text { tree } \\
\text { species }^{\mathrm{b}}\end{array}$ & $\begin{array}{l}\text { Canopy } \\
\text { cover }(\%)\end{array}$ & $\begin{array}{l}\text { Rockiness/ } \\
\text { Stoniness } \\
(\%)\end{array}$ & Horizon sequence ${ }^{c}$ & $\begin{array}{l}\text { Soil classification } \\
\text { (IUSS Working Group WRB, 2014) }\end{array}$ \\
\hline P1 & $400037 \mathrm{E} 4882717 \mathrm{~N}$ & 1321 & FLY & PS & 40 & 50 & $\mathrm{~A} / \mathrm{O}-\mathrm{AC}-\mathrm{C}-2 \mathrm{Btb}$ & $\begin{array}{l}\text { Abruptic Skeletic Alisol (Loamic, Colluvic, Cutanic, Differentic, } \\
\text { Humic, Ruptic, Loaminovic) }\end{array}$ \\
\hline $\mathrm{P} 2$ & $399980 \mathrm{E} 4882840 \mathrm{~N}$ & 1312 & FLY & FS & 100 & 1 & $\mathrm{~A} 1-\mathrm{A} 2-\mathrm{AC}-\mathrm{C} 1-2 \mathrm{C} 2$ & Skeletic Colluvic Protic Dystric Regosol (Loamic, Humic) \\
\hline P3 & $397859 \mathrm{E} 4884942 \mathrm{~N}$ & 1635 & FLY & LD & 10 & 0 & $\mathrm{~A}-\mathrm{Bw}-\mathrm{BC}-2 \mathrm{C} 1-2 \mathrm{C} 2$ & Skeletic Hypereutric Cambisol (Loamic, Humic) \\
\hline $\mathrm{P} 4$ & $411567 \mathrm{E} 4886042 \mathrm{~N}$ & 820 & LIM & FO & 60 & 20 & $\begin{array}{l}\mathrm{A} 1-\mathrm{A} 2-\mathrm{Bk} 1-\mathrm{Bk} 2- \\
\mathrm{CBk}^{*}\end{array}$ & Calcic Skeletic Kastanozem (Loamic) \\
\hline P5 & $399731 \mathrm{E} 4887975 \mathrm{~N}$ & 1200 & LIM & PS & 80 & 50 & $\mathrm{~A} 1-\mathrm{A} 2-\mathrm{AB}-2 \mathrm{Bw}$ & $\begin{array}{l}\text { Folic Episkeletic Dolomitic Hypereutric Cambisol (Loamic, } \\
\text { Colluvic, Humic) }\end{array}$ \\
\hline P6 & 410929E 4885808N & 838 & LIM & FS & 100 & 1 & $\mathrm{~A} 1-\mathrm{A} 2-\mathrm{CBk}^{*}$ & Calcic Skeletic Chernozem (Loamic, Colluvic, Hyperhumic) \\
\hline P7 & $399563 \mathrm{E} 4887980 \mathrm{~N}$ & 1230 & LIM & FS & 100 & 10 & $\mathrm{~A}-\mathrm{ABt}-\mathrm{Bt} / \mathrm{A}$ & $\begin{array}{l}\text { Chromic Orthoskeletic Luvisol (Clayic, Cutanic, Hypereutric, } \\
\text { Hyperhumic, Profondic) }\end{array}$ \\
\hline P8 & $397372 \mathrm{E} 4884765 \mathrm{~N}$ & 1666 & FLY & LD & 20 & 0 & $\mathrm{~A} 1-\mathrm{A} 2-\mathrm{AC}-\mathrm{C}$ & Skeletic Colluvic Protic Orthodystric Regosol (Loamic, Humic) \\
\hline P9 & $400283 \mathrm{E} 4888776 \mathrm{~N}$ & 1234 & QTZ & PS & 80 & 10 & $\mathrm{~A}-\mathrm{Bw}-\mathrm{BC}$ & Skeletic Hyperdystric Cambisol (Loamic, Humic) \\
\hline $\mathrm{P} 10$ & 403444E 4887760N & 1238 & QTZ & FS & 100 & 5 & $\mathrm{~A}-\mathrm{AC}-\mathrm{Cr}$ & Skeletic Protic Hyperdystric Regosol (Loamic, Humic) \\
\hline P11 & $413023 \mathrm{E} 4884993 \mathrm{~N}$ & 1021 & FLY & FS & 100 & 5 & $\mathrm{~A} 1-\mathrm{A} 2-\mathrm{AC}-\mathrm{Cr}$ & Folic Protic Orthoeutric Regosol (Loamic, Humic) \\
\hline P12 & $412710 \mathrm{E} 4885631 \mathrm{~N}$ & 1032 & FLY & $\mathrm{CS}$ & 100 & 5 & $\mathrm{~A}-\mathrm{C} 1-\mathrm{C} 2$ & Amphiskeletic Protic Hyperdystric Regosol (Loamic, Humic) \\
\hline $\mathrm{P} 13$ & $419232 \mathrm{E} 4885153 \mathrm{~N}$ & 1305 & QTZ & FS & 100 & 10 & $\mathrm{~A}^{*}$-E*-Bs1-Bs2 & Albic Skeletic Podzol (Loamic) \\
\hline P14 & $417426 \mathrm{E} 4887846 \mathrm{~N}$ & 1104 & QTZ & $\mathrm{CS}$ & 70 & 1 & $\begin{array}{l}\mathrm{A} 1 *-\mathrm{A} 2-\mathrm{BtA}-\mathrm{Btb} 1- \\
\mathrm{Btb} 2\end{array}$ & Skeletic Luvisol (Loamic, Cutanic, Escalic, Humic, Profondic) \\
\hline P15 & $412849 \mathrm{E} 4890221 \mathrm{~N}$ & 875 & FLY & $\mathrm{CS}$ & 100 & 10 & $\mathrm{~A} 1-\mathrm{A} 2-\mathrm{AC}-\mathrm{Ab}-\mathrm{ACb}$ & Protic Orthodystric Regosol (Loamic, Escalic, Humic, Transportic) \\
\hline P16 & 420098E 4891086N & 1411 & LIM & FS & 100 & 5 & A-Bw1-Bw2-CB & Calcaric Hypereutric Cambisol (Loamic, Humic) \\
\hline P17 & $419760 \mathrm{E} 4890689 \mathrm{~N}$ & 970 & QTZ & $\mathrm{CS}$ & 80 & 10 & $\mathrm{~A}-\mathrm{Bw}-\mathrm{BAb}-\mathrm{C} 1 \mathrm{~b}-\mathrm{C} 2 \mathrm{~b}$ & $\begin{array}{l}\text { Orthoskeletic Hyperdystric Cambisol (Loamic, Escalic, Humic) over } \\
\text { Skeletic Protic Hyperdystric Regosol (Loamic) }\end{array}$ \\
\hline P18 & 419578E 4890351N & 967 & FLY & $\mathrm{CS}$ & 100 & 1 & $\begin{array}{l}\text { A-AB1-AB2-Btb1- } \\
\text { Btb2-Btb3-Cb* }\end{array}$ & $\begin{array}{l}\text { Haplic Luvisol (Clayic, Cutanic, Epidystric, Escalic, Humic, Nechic, } \\
\text { Loaminovic, Profondic, Transportic) }\end{array}$ \\
\hline P19 & 403790E 4889299N & 1728 & QTZ & PS & 60 & 5 & $\begin{array}{l}\text { AE1-AE2-Bs-Bsm1- } \\
\text { Bsm2 }\end{array}$ & Ortsteinic Albic Skeletic Podzol (Loamic) \\
\hline $\mathrm{P} 20$ & $418912 \mathrm{E} 4890453 \mathrm{~N}$ & 885 & FLY & FO & 100 & 5 & $\mathrm{~A} / \mathrm{Bw}-\mathrm{AB}-\mathrm{Bw}-\mathrm{BC}$ & Orthoeutric Cambisol (Loamic, Humic) \\
\hline
\end{tabular}

${ }^{a}$ FLY: calcareous and non-calcareous, weakly metamorphosed siltstones, claystones and sandstones; LIM: limestone and/or dolostone; QTZ: quartzite or porphiroids.

b PS: Pinus sylvestris L. or Pinus montana Miller; FS: Fagus sylvatica L.; LD: Larix decidua Mill. associated with grassland; FO: Fraxinus ornus L. and Ostrya carpinifolia Scop. association; CS: Castanea sativa Mill.

${ }^{c}$ Organic horizons were present at all sites and not reported. 
Table 2 - Mean values of selected characteristics of the mineral soil samples according to master horizon, vegetation, parent material and soil classification. The standard deviation is given in parentheses.

\begin{tabular}{|c|c|c|c|c|c|c|c|c|c|c|}
\hline $\begin{array}{c}\text { Horizo } \\
\mathrm{n}\end{array}$ & $\begin{array}{c}\text { Parent } \\
\text { material }^{\mathrm{a}}\end{array}$ & $\begin{array}{l}\text { Vegeta } \\
\text { tion }^{\mathrm{b}}\end{array}$ & $\mathrm{n}$ & $\begin{array}{c}\mathrm{OC}_{\mathrm{UT}} \\
\left(\mathrm{g} \mathrm{kg}^{-1}\right)\end{array}$ & $\mathrm{C}_{\mathrm{UT}} / \mathrm{N}$ & $\mathrm{pH}$ & $\begin{array}{l}\text { Sand } \\
(\%)\end{array}$ & $\begin{array}{l}\text { Clay } \\
(\%)\end{array}$ & $\begin{array}{c}\mathrm{Fe}_{\mathrm{D}} \\
\left(\mathrm{g} \mathrm{kg}^{-1}\right)\end{array}$ & $\begin{array}{c}\mathrm{Fe}_{\mathrm{O}} \\
\left(\mathrm{g} \mathrm{kg}^{-1}\right)\end{array}$ \\
\hline \multirow[t]{11}{*}{ A } & LIM & PS & 3 & $47.9(16.2)$ & $20.0(2.8)$ & $7.8(0.1)$ & $24.3(1.4)$ & $29.8(1.5)$ & $16.7(1.6)$ & $2.1(0.6)$ \\
\hline & & FS & 5 & $65.6(19.2)$ & $16.0(1.8)$ & $7.3(1.2)$ & $23.3(10.8)$ & $34.2(15.2)$ & $19.0(7.3)$ & $2.3(0.8)$ \\
\hline & & FO & 2 & $46.6(3.9)$ & $12.2(1.0)$ & $7.9(0.1)$ & $29.3(3.4)$ & $31.5(2.2)$ & $19.3(3.4)$ & $2.1(0.0)$ \\
\hline & FLY & PS & 2 & $51.5(44.1)$ & $21.0(6.9)$ & $4.9(0.2)$ & $53.6(11.8)$ & $17.9(5.9)$ & $8.2(1.0)$ & $3.2(0.6)$ \\
\hline & & FS & 6 & $42.2(41.5)$ & $12.4(2.7)$ & $5.6(0.3)$ & $53.7(12.6)$ & $20.6(9.7)$ & $12.4(6.3)$ & $3.2(1.1)$ \\
\hline & & $\mathrm{CS}$ & 9 & $17.7(7.6)$ & $13.8(7.8)$ & $5.6(0.9)$ & $46.1(8.6)$ & $24.6(8.3)$ & $17.5(3.6)$ & $3.6(0.9)$ \\
\hline & & LD & 4 & $50.5(35.6)$ & $12.8(1.5)$ & $5.7(0.3)$ & $43.9(18.0)$ & $25.8(10.5)$ & $12.1(3.1)$ & $4.3(1.0)$ \\
\hline & & FO & 2 & $18.2(4.7)$ & $17.2(1.0)$ & $6.4(0.2)$ & $56.2(2.0)$ & $13.3(0.1)$ & $12.2(1.5)$ & $0.5(0.0)$ \\
\hline & QTZ & PS & 3 & $37.2(26.7)$ & $32.3(8.4)$ & $4.1(0.1)$ & $72.5(6.2)$ & $8.2(2.6)$ & $5.6(2.8)$ & $1.6(2.2)$ \\
\hline & & FS & 2 & $20.4(4.7)$ & $15.9(1.5)$ & $4.7(0.1)$ & $62.0(3.4)$ & $14.0(1.2)$ & $6.9(1.9)$ & $1.3(0.5)$ \\
\hline & & CS & 2 & $53.2(49.7)$ & $17.8(0.2)$ & $4.5(0.1)$ & $51.8(13.4)$ & $15.1(3.4)$ & $10.5(10.4)$ & $1.3(1.8)$ \\
\hline \multirow[t]{10}{*}{ B } & LIM & PS & 1 & 23.4 & 16.1 & 8.0 & 29.7 & 30.9 & 19.6 & 2.1 \\
\hline & & FS & 3 & $27.6(10.9)$ & $12.8(2.3)$ & $7.6(0.4)$ & $19.6(3.4)$ & $33.9(11.7)$ & $27.9(0.9)$ & $4.3(1.4)$ \\
\hline & & FO & 2 & $43.0(6.7)$ & $12.6(1.4)$ & $8.0(0.1)$ & $23.8(4.6)$ & $27.5(8.7)$ & $22.6(0.3)$ & $1.9(0.3)$ \\
\hline & FLY & PS & 1 & 8.3 & 7.5 & 5.8 & 34.5 & 35.5 & 17.8 & 3.7 \\
\hline & & FS & 3 & $4.5(0.4)$ & $11.2(0.9)$ & $6.7(0.6)$ & $20.4(0.4)$ & 47.7 (3.8) & 27.7 (4.1) & $4.0(0.6)$ \\
\hline & & CS & 2 & $22.5(6.7)$ & $9.0(0.6)$ & $6.0(0.0)$ & $26.5(5.0)$ & $35.1(4.6)$ & $18.0(0.1)$ & $3.3(0.1)$ \\
\hline & & FO & 2 & $7.3(0.5)$ & $18.1(1.2)$ & $6.8(0.2)$ & $54.7(3.2)$ & $13.9(0.1)$ & $17.9(2.8)$ & $0.5(0.1)$ \\
\hline & QTZ & PS & 5 & $15.3(8.1)$ & $23.1(1.7)$ & $5.0(0.3)$ & $63.2(11.5)$ & $10.9(8.1)$ & $8.9(2.7)$ & $3.0(1.9)$ \\
\hline & & FS & 2 & $16.7(3.0)$ & $20.9(0.0)$ & $4.2(0.0)$ & 40.7 (1.6) & $20.9(4.1)$ & $12.5(7.7)$ & $3.6(1.9)$ \\
\hline & & CS & 5 & $10.1(4.0)$ & $16.0(5.2)$ & $4.8(0.1)$ & $52.2(13.5)$ & $18.9(8.3)$ & $12.1(8.0)$ & $2.9(1.5)$ \\
\hline \multirow[t]{7}{*}{$\mathrm{C}$} & LIM & FS & 1 & 11.8 & 9.4 & 8.3 & 32.9 & 20.0 & 24.1 & 2.7 \\
\hline & FLY & PS & 1 & 11.6 & 11.1 & 5.5 & 57.2 & 16.0 & 8.5 & 2.4 \\
\hline & & FS & 3 & $10.9(2.7)$ & $9.3(0.2)$ & $5.6(0.1)$ & $61.0(5.0)$ & $16.1(4.3)$ & $13.2(3.5)$ & $3.1(0.5)$ \\
\hline & & CS & 2 & $8.6(0.5)$ & $9.1(0.2)$ & $5.3(0.0)$ & $46.7(5.1)$ & $27.3(1.3)$ & $16.6(1.1)$ & $2.5(0.2)$ \\
\hline & & LD & 3 & $9.8(4.1)$ & $8.0(2.2)$ & $6.9(1.3)$ & $49.7(8.8)$ & $18.5(6.7)$ & $15.0(3.5)$ & $2.9(1.6)$ \\
\hline & QTZ & FS & 1 & 16.7 & 15.9 & 4.8 & 53.8 & 18.8 & 8.0 & 2.2 \\
\hline & & CS & 2 & $6.3(0.5)$ & $11.4(0.6)$ & $4.9(0.0)$ & $71.8(1.1)$ & $8.5(0.5)$ & $3.8(1.4)$ & $1.5(0.9)$ \\
\hline $\begin{array}{l}\text { Horizo } \\
\mathrm{n}\end{array}$ & Soil Group & & & & & & & & & \\
\hline \multirow[t]{5}{*}{ A } & RG & & 17 & $31.1(28.8)$ & $11.8(2.9)$ & $5.6(0.6)$ & $50.6(10.1)$ & $22.5(7.5)$ & $13.8(5.8)$ & $3.5(1.3)$ \\
\hline & $\mathrm{CB}$ & & 9 & $56.1(28.3)$ & $20.7(8.5)$ & $6.3(1.4)$ & $38.2(21.1)$ & $24.5(12.3)$ & $13.5(5.2)$ & $1.8(1.3)$ \\
\hline & LV & & 8 & $37.4(30.9)$ & $19.9(5.7)$ & $5.6(1.3)$ & $42.7(18.5)$ & $25.1(15.4)$ & $16.1(7.3)$ & $3.1(0.6)$ \\
\hline & ML & & 4 & $49.9(12.4)$ & $13.8(2.0)$ & $8.0(0.1)$ & $32.1(4.0)$ & $24.8(7.8)$ & $15.4(4.9)$ & $1.9(0.2)$ \\
\hline & PD & & 2 & $22.1(8.3)$ & $27.5(0.7)$ & $4.0(0.0)$ & $75.6(4.0)$ & $7.1(2.6)$ & $4.0(1.1)$ & $0.3(0.1)$ \\
\hline \multirow[t]{4}{*}{ B } & $\mathrm{CB}$ & & 11 & $18.0(8.1)$ & $15.2(5.3)$ & $6.2(1.3)$ & $42.5(17.6)$ & $22.4(10.3)$ & $15.5(8.9)$ & $2.4(1.8)$ \\
\hline & LV & & 8 & $10.9(11.4)$ & $13.7(5.3)$ & $6.0(1.1)$ & $30.1(12.7)$ & $37.1(11.4)$ & $22.7(5.6)$ & $3.7(0.9)$ \\
\hline & ML & & 2 & $43.0(6.7)$ & $12.6(1.4)$ & $8.0(0.1)$ & $23.8(4.6)$ & $27.5(8.7)$ & $22.6(0.3)$ & $1.9(0.3)$ \\
\hline & PD & & 5 & $12.5(4.5)$ & $22.0(1.6)$ & $4.7(0.5)$ & $59.2(17.0)$ & $11.5(9.0)$ & $10.8(4.8)$ & $3.7(1.4)$ \\
\hline \multirow[t]{3}{*}{$\mathrm{C}$} & RG & & 7 & $11.5(3.3)$ & $10.3(2.5)$ & $5.4(0.3)$ & $55.4(7.4)$ & $20.0(5.7)$ & $13.4(3.6)$ & $3.0(0.8)$ \\
\hline & $\mathrm{CB}$ & & 5 & $8.0(2.8)$ & $9.2(2.4)$ & $6.7(1.7)$ & $53.6(17.8)$ & $14.9(7.5)$ & $12.8(9.1)$ & $2.0(0.9)$ \\
\hline & LV & & 1 & 11.6 & 11.1 & 5.5 & 57.2 & 16.0 & 8.5 & 2.4 \\
\hline
\end{tabular}

${ }^{a}$ FLY: calcareous and non-calcareous weakly metamorphosed siltstones, claystones and sandstones ; LIM: limestone and/or dolostone; QTZ: quartzite or porphiroids.

${ }^{\mathrm{b}}$ PS: Pinus sylvestris L. or Pinus montana Miller; FS: Fagus sylvatica L.; CS: Castanea sativa Mill.; LD: Larix decidua Mill. associated with grassland; FO: Fraxinus ornus L. and Ostrya carpinifolia Scop. association.

${ }^{\mathrm{c}}$ RG: Regosols; CB: Cambisols; LV: Luvisols/Alisols; ML: Chernozems/Kastanozems; PD: Podzols. 
Table 3 - Effects of vegetation, parent material and their interaction (two-way ANOVA; $\mathrm{n}=5$ vegetation, $\mathrm{n}=3$ lithology), and of soil type (one-way ANOVA) on soil characteristics $(* P<0.05 ; * * P<0.01$ ).

\begin{tabular}{|c|c|c|c|c|c|c|c|c|c|c|c|}
\hline \multirow[t]{2}{*}{ Parameter } & \multirow[t]{2}{*}{ Horizon } & \multicolumn{2}{|c|}{ Model $^{\mathrm{a}}$} & \multicolumn{2}{|c|}{ Vegetation $^{\mathrm{a}}$} & \multicolumn{2}{|c|}{ Lithology } & \multicolumn{2}{|c|}{$\begin{array}{l}\text { Vegetation } \mathrm{x} \\
\text { Lithology }^{\mathrm{a}}\end{array}$} & \multicolumn{2}{|c|}{ Soil type } \\
\hline & & $\mathrm{F}$ & $P$ & $\mathrm{~F}$ & $P$ & $\mathrm{~F}$ & $P$ & $\mathrm{~F}$ & $P$ & $\mathrm{~F}$ & $P$ \\
\hline \multirow[t]{3}{*}{$\begin{array}{l}\mathrm{OC}_{\mathrm{UT}}\left(\mathrm{g} \mathrm{kg}^{-}\right. \\
\left.{ }^{1}\right)\end{array}$} & A & $2.449^{c}$ & $0.029 *$ & 0.839 & 0.512 & 3.592 & $0.040^{*}$ & 0.994 & 0.427 & 1.545 & 0.211 \\
\hline & B & $6.094^{c}$ & $0.001 * *$ & 7.042 & $0.002 * *$ & 7.273 & $0.006^{* *}$ & 0.578 & 0.638 & 7.598 & $0.001^{* *}$ \\
\hline & $\mathrm{C}$ & 1.725 & 0.262 & 2.929 & 0.122 & 0.418 & 0.676 & 3.465 & 0.112 & 1.932 & 0.195 \\
\hline \multirow[t]{3}{*}{$\mathrm{C}_{\mathrm{UT}} / \mathrm{N}$} & A & $3.489^{\mathrm{d}}$ & $0.004^{* *}$ & 3.744 & $0.014^{*}$ & 2.912 & 0.070 & 1.115 & 0.369 & 8.299 & $0.000^{* *}$ \\
\hline & B & $8.748^{\mathrm{d}}$ & $0.000^{* *}$ & 2.717 & 0.067 & 19.527 & $0.000^{* *}$ & 5.416 & $0.008^{* *}$ & 3.819 & $0.024 *$ \\
\hline & $\mathrm{C}$ & 5.308 & $0.031 *$ & 3.339 & 0.097 & 10.682 & $0.011^{*}$ & 4.527 & 0.077 & 0.469 & 0.639 \\
\hline \multirow[t]{3}{*}{$\mathrm{pH}$} & $\mathrm{A}$ & 11.001 & $0.000^{* *}$ & 1.178 & 0.341 & 38.098 & $0.000 * *$ & 0.926 & 0.463 & $6.508^{c}$ & $0.001 * *$ \\
\hline & $\mathrm{B}$ & 49.352 & $0.000^{* *}$ & 4.347 & $0.014^{*}$ & 147.992 & $0.000^{* *}$ & 2.969 & 0.063 & 4.365 & $0.015^{*}$ \\
\hline & $\mathrm{C}$ & 4.132 & 0.054 & 2.689 & 0.140 & 6.708 & $0.030^{*}$ & 0.075 & 0.793 & $1.388^{\mathrm{c}}$ & $0.022 *$ \\
\hline \multirow{3}{*}{ Sand (\%) } & A & 7.059 & $0.000 * *$ & 1.825 & 0.151 & 29.230 & $0.000^{* *}$ & 0.379 & 0.822 & $2.689^{c}$ & $0.047 *$ \\
\hline & B & $16.347^{\mathrm{d}}$ & $0.000^{* *}$ & 8.884 & $0.001^{* *}$ & 37.531 & $0.000^{* *}$ & 4.785 & $0.014^{*}$ & $3.947^{\mathrm{d}}$ & $0.022 *$ \\
\hline & $\mathrm{C}$ & 6.028 & $0.023^{*}$ & 0.509 & 0.691 & 6.651 & $0.030^{*}$ & 11.66 & 0.014 & $0.169^{d}$ & 0.847 \\
\hline \multirow[t]{3}{*}{ Clay (\%) } & A & $3.425^{\mathrm{d}}$ & $0.005^{* *}$ & 1.493 & 0.230 & 13.465 & $0.000^{* *}$ & 0.495 & 0.739 & $2.843^{\mathrm{d}}$ & $0.038^{*}$ \\
\hline & B & $1.193^{c}$ & 0.363 & 0.470 & 0.757 & 1.764 & 0.203 & 0.632 & 0.605 & 6.680 & $0.002 * *$ \\
\hline & $\mathrm{C}$ & 2.915 & 0.109 & 0.569 & 0.656 & 2.598 & 0.154 & 9.326 & $0.022 *$ & 0.934 & 0.425 \\
\hline \multirow[t]{3}{*}{$\mathrm{Fe}_{\mathrm{D}}\left(\mathrm{g} \mathrm{kg}^{-1}\right)$} & A & $3.745^{\mathrm{d}}$ & $0.003 * *$ & 1.305 & 0.291 & 13.219 & $0.000^{* *}$ & 0.246 & 0.910 & 1.790 & 0.153 \\
\hline & B & $2.421^{\mathrm{d}}$ & 0.059 & 0.468 & 0.758 & 6.755 & $0.007 * *$ & 0.180 & 0.908 & 3.529 & $0.032 *$ \\
\hline & $\mathrm{C}$ & 7.005 & $0.016^{*}$ & 1.375 & 0.338 & 12.977 & $0.007 * *$ & 2.836 & 0.143 & 0.250 & 0.783 \\
\hline \multirow[t]{3}{*}{$\mathrm{Fe}_{\mathrm{O}}\left(\mathrm{g} \mathrm{kg}^{-1}\right)$} & A & $5.257^{\mathrm{d}}$ & $0.000 * *$ & 5.938 & $0.001 * *$ & 6.654 & $0.004 * *$ & 2.940 & $0.038^{*}$ & $24.774^{\mathrm{c}}$ & $0.000 * *$ \\
\hline & B & 1.345 & 0.290 & 2.515 & 0.083 & 0.295 & 0.749 & 0.678 & 0.578 & 1.982 & 0.146 \\
\hline & $\mathrm{C}$ & 0.601 & 0.724 & 0.309 & 0.819 & 0.812 & 0.488 & 0.002 & 0.969 & 2.378 & 0.143 \\
\hline
\end{tabular}

${ }^{a}$ Dfs are 10, 4, 2, 4 for model, vegetation lithology and interaction, respectively, in the case of the analysis of variance in A horizons; 9, 4, 2, 3 in $\mathrm{B}$ ones and 6, 3, 2, 1 in $\mathrm{C}$ ones.

${ }^{\mathrm{b}}$ Dfs are 4, 35, 39 among groups, within groups and total, respectively for A horizons; 3, 22, 25 for B horizons and 2, 10, 12 for $\mathrm{C}$ ones.

${ }^{\mathrm{c}}$ The variables were inverse transformed before the analysis

d The variables were LG10 transformed before the analysis 
Table 4 - Amount and proportion of chemically fractionated organic carbon pools of mineral soil samples. $\mathrm{OC}_{\text {lab: }}$ NaClO-labile OC; $\mathrm{OC}_{\text {rec: }}$ chemically recalcitrant $\mathrm{OC}$; $\mathrm{OC}_{\min }$ : mineral-associated OC.

\begin{tabular}{|c|c|c|c|c|c|c|c|c|c|}
\hline Horizon & Lithology & Vegetation $^{\mathrm{b}}$ & $\mathrm{n}$ & $\begin{array}{l}\mathrm{OC}_{\text {lab }} \\
\mathrm{g} \mathrm{kg}^{-1}\end{array}$ & $\begin{array}{l}\mathrm{OC}_{\mathrm{rec}} \\
\mathrm{g} \mathrm{kg}^{-1}\end{array}$ & $\begin{array}{l}\mathrm{OC}_{\min } \\
\mathrm{g} \mathrm{kg}^{-1}\end{array}$ & $\begin{array}{c}\mathrm{OC}_{\mathrm{lab}} \\
\% \mathrm{OC}_{\mathrm{UT}}\end{array}$ & $\begin{array}{c}\mathrm{OC}_{\mathrm{rec}} \\
\% \mathrm{OC}_{\mathrm{UT}}\end{array}$ & $\begin{array}{c}\mathrm{OC}_{\min } \\
\% \mathrm{OC}_{\mathrm{UT}}\end{array}$ \\
\hline \multirow[t]{11}{*}{$\mathrm{A}$} & LIM & PS & 3 & $42.4(13.2)$ & $4.4(2.1)$ & $1.1(1.1)$ & $89.1(2.8)$ & $8.8(2.5)$ & $2.1(1.5)$ \\
\hline & & FS & 5 & $56.0(16.9)$ & $5.9(3.0)$ & $3.7(2.6)$ & $85.2(3.1)$ & $8.5(2.5)$ & $6.3(4.6)$ \\
\hline & & FO & 2 & $41.5(0.6)$ & $3.3(0.9)$ & $1.8(2.5)$ & $89.3(6.2)$ & $7.0(1.2)$ & $3.7(5.0)$ \\
\hline & FLY & PS & 2 & $42.4(35.7)$ & $6.9(6.9)$ & $2.1(1.5)$ & $83.4(2.1)$ & $12.1(3.2)$ & $4.6(1.0)$ \\
\hline & & FS & 6 & $37.3(38.7)$ & $4.0(3.2)$ & $0.8(0.2)$ & $85.2(5.7)$ & $11.0(3.9)$ & $3.8(3.5)$ \\
\hline & & $\mathrm{CS}$ & 9 & $13.9(6.0)$ & $2.2(1.8)$ & $1.5(0.6)$ & $79.3(5.9)$ & $11.4(5.9)$ & $9.4(2.7)$ \\
\hline & & LD & 4 & $44.6(31.3)$ & $4.8(4.5)$ & $1.1(0.5)$ & $88.4(1.2)$ & $8.2(3.0)$ & $3.3(2.3)$ \\
\hline & & FO & 2 & $16.2(4.5)$ & $1.6(0.9)$ & $0.4(0.6)$ & $88.9(1.4)$ & $8.5(2.9)$ & $2.8(4.0)$ \\
\hline & QTZ & PS & 3 & $29.3(19.7)$ & $5.9(4.8)$ & $2.0(2.3)$ & $80.6(3.9)$ & $15.0(1.6)$ & $4.4(2.5)$ \\
\hline & & FS & 2 & $16.7(3.7)$ & $3.5(1.2)$ & $0.2(0.2)$ & $81.8(0.7)$ & $16.9(1.9)$ & $1.3(1.3)$ \\
\hline & & CS & 2 & $44.1(43.3)$ & $7.8(7.1)$ & $1.2(0.7)$ & $79.8(6.9)$ & $15.1(0.8)$ & $5.2(6.1)$ \\
\hline \multirow[t]{10}{*}{ B } & LIM & PS & 1 & 20.6 & 1.7 & 1.2 & 87.9 & 7.1 & 5.0 \\
\hline & & FS & 3 & $24.0(9.7)$ & $2.2(0.9)$ & $1.4(0.3)$ & $86.7(1.1)$ & $7.7(1.2)$ & $5.5(1.5)$ \\
\hline & & FO & 2 & $40.4(7.3)$ & $1.8(0.4)$ & $0.8(1.1)$ & $93.9(2.5)$ & $4.1(0.3)$ & $2.0(2.8)$ \\
\hline & FLY & PS & 1 & 6.9 & 0.6 & 0.8 & 83.4 & 7.1 & 9.4 \\
\hline & & CS & 3 & $3.2(0.2)$ & $0.3(0.1)$ & $0.9(0.1)$ & $72.2(1.1)$ & $7.0(1.6)$ & $20.8(1.9)$ \\
\hline & & LD & 2 & $19.4(4.9)$ & $2.1(0.9)$ & $1.0(0.8)$ & $86.8(3.7)$ & $8.9(1.5)$ & $4.3(2.1)$ \\
\hline & & FO & 2 & $6.1(0.5)$ & $0.2(0.1)$ & $0.9(0.1)$ & 84.1 (1.6) & $3.3(2.0)$ & $12.6(0.4)$ \\
\hline & QTZ & PS & 5 & $10.9(6.2)$ & $2.4(2.7)$ & $2.0(0.9)$ & $69.8(4.7)$ & $11.9(10.3)$ & $18.3(13.5)$ \\
\hline & & FS & 2 & $12.1(2.6)$ & $3.4(0.3)$ & $1.2(0.1)$ & $72.2(2.6)$ & $20.5(1.9)$ & $7.3(0.8)$ \\
\hline & & $\mathrm{CS}$ & 5 & $8.3(3.7)$ & $0.8(0.3)$ & $1.0(0.7)$ & $80.2(9.3)$ & $8.4(2.1)$ & $11.4(9.3)$ \\
\hline \multirow[t]{7}{*}{$\mathrm{C}$} & LIM & PS & 1 & 11.0 & 0.3 & 0.5 & 93.1 & 2.9 & 4.0 \\
\hline & FLY & PS & 1 & 9.6 & 1.4 & 0.5 & 83.3 & 12.1 & 4.6 \\
\hline & & FS & 3 & $8.8(3.2)$ & $1.2(0.2)$ & $0.9(0.3)$ & $79.2(8.5)$ & $11.7(3.7)$ & $9.2(4.8)$ \\
\hline & & CS & 2 & $6.8(0.7)$ & $1.2(0.6)$ & $0.7(0.8)$ & $78.4(3.2)$ & $13.7(6.6)$ & $7.9(9.9)$ \\
\hline & & LD & 3 & $8.6(3.4)$ & $0.6(0.2)$ & $0.6(0.5)$ & $88.4(2.3)$ & $6.2(1.2)$ & $5.4(3.2)$ \\
\hline & QTZ & FS & 1 & 14.1 & 1.8 & 0.8 & 84.7 & 10.8 & 4.6 \\
\hline & & CS & 2 & $5.3(0.5)$ & $0.6(0.0)$ & $0.4(0.0)$ & $84.4(0.6)$ & $9.2(0.8)$ & $6.3(0.1)$ \\
\hline
\end{tabular}

${ }^{a}$ FLY: calcareous and non-calcareous weakly metamorphosed siltstones, claystones and sandstones ; LIM: limestone and/or dolostone; QTZ: quartzite or porphiroids.

${ }^{\mathrm{b}}$ PS: Pinus sylvestris L. or and Pinus montana Miller; FS: Fagus sylvatica L.; LD: Larix decidua Mill. associated with grassland; FO: Fraxinus ornus L. and Ostrya carpinifolia Scop. association; CS: Castanea sativa Mill. 
Table 5 - Effects of vegetation, parent material and their interaction (two-way ANOVA; $\mathrm{n}=5$ vegetation, $\mathrm{n}=3$ lithology), and of soil type (one-way ANOVA), on organic matter pools. (* $P<0.05$; ** $P<0.01$ ).

\begin{tabular}{|c|c|c|c|c|c|c|c|c|c|c|c|}
\hline \multirow[t]{2}{*}{ Parameter } & \multirow[t]{2}{*}{ Horizon } & \multicolumn{2}{|c|}{ Model $^{\mathrm{a}}$} & \multicolumn{2}{|c|}{ Vegetation $^{\mathrm{a}}$} & \multicolumn{2}{|c|}{ Lithology $^{\mathrm{a}}$} & \multicolumn{2}{|c|}{ Vegetation $\mathrm{x}$ Lithology $\mathrm{y}^{\mathrm{a}}$} & \multicolumn{2}{|c|}{ Soil type ${ }^{b}$} \\
\hline & & $\mathrm{F}$ & $P$ & $\mathrm{~F}$ & $P$ & $\mathrm{~F}$ & $P$ & $\mathrm{~F}$ & $P$ & $\mathrm{~F}$ & $P$ \\
\hline \multirow{3}{*}{$\mathrm{OC}_{\mathrm{lab}}\left(\mathrm{g} \mathrm{kg}^{-1}\right)$} & $\mathrm{A}$ & $2.696^{\mathrm{c}}$ & $0.018^{*}$ & 1.062 & 0.393 & 3.507 & $0.043 *$ & 0.944 & 0.453 & $2.323^{\mathrm{d}}$ & 0.076 \\
\hline & $\mathrm{B}$ & $4.395^{\mathrm{c}}$ & $0.005^{* *}$ & 5.202 & $0.007 * *$ & 4.269 & $0.033^{*}$ & 0.808 & 0.508 & $5.908^{\mathrm{e}}$ & $0.004^{* *}$ \\
\hline & $\mathrm{C}$ & 1.482 & 0.322 & 2.355 & 0.171 & 0.432 & 0.668 & 2.671 & 0.153 & 0.879 & 0.445 \\
\hline \multirow[t]{3}{*}{$\mathrm{OC}_{\mathrm{rec}}\left(\mathrm{g} \mathrm{kg}^{-1}\right)$} & A & $1.245^{\mathrm{e}}$ & 0.306 & 0.471 & 0.757 & 1.189 & 0.319 & 0.789 & 0.542 & $1.318^{\mathrm{e}}$ & 0.282 \\
\hline & B & $2.341^{\mathrm{d}}$ & 0.066 & 2.587 & 0.077 & 2.928 & 0.083 & 0.688 & 0.572 & $1.253^{\mathrm{e}}$ & 0.315 \\
\hline & $\mathrm{C}$ & $4.847^{\mathrm{c}}$ & $0.038^{*}$ & 4.924 & $0.047^{*}$ & 10.747 & $0.010 * *$ & 2.389 & 0.173 & $16.300^{\mathrm{e}}$ & $0.001 * *$ \\
\hline \multirow[t]{3}{*}{$\mathrm{OC}_{\min }\left(\mathrm{g} \mathrm{kg}^{-1}\right)$} & A & $1.242^{\mathrm{f}}$ & 0.307 & 0.155 & 0.959 & 1.101 & 0.346 & 1.428 & 0.250 & $4.903^{\mathrm{f}}$ & $0.003^{* *}$ \\
\hline & B & $0.737^{\mathrm{e}}$ & 0.671 & 0.217 & 0.925 & 0.388 & 0.685 & 0.689 & 0.573 & $3.225^{\mathrm{e}}$ & $0.043^{*}$ \\
\hline & $\mathrm{C}$ & $0.427^{\mathrm{f}}$ & 0.838 & 0.470 & 0.714 & 0.937 & 0.443 & 0.084 & 0.782 & 2.146 & 0.168 \\
\hline \multirow{3}{*}{$\mathrm{OC}_{\mathrm{lab}}\left(\% \mathrm{OC}_{\mathrm{UT}}\right)$} & A & $2.481^{\mathrm{e}}$ & $0.027^{*}$ & 2.384 & 0.074 & 1.656 & 0.208 & 0.592 & 0.671 & 1.339 & 0.275 \\
\hline & B & $5.277^{\mathrm{e}}$ & $0.002 * *$ & 1.391 & 0.281 & 7.112 & $0.006^{* *}$ & 3.232 & $0.050^{*}$ & 10.741 & $0.000^{* *}$ \\
\hline & $\mathrm{C}$ & 1.679 & 0.272 & 2.099 & 0.202 & 3.391 & 0.103 & 0.005 & 0.947 & 2.892 & 0.102 \\
\hline \multirow[t]{3}{*}{$\mathrm{OC}_{\mathrm{rec}}\left(\% \mathrm{OC}_{\mathrm{UT}}\right)$} & A & 1.770 & 0.112 & 0.708 & 0.593 & 5.561 & $0.009 * *$ & 0.132 & 0.969 & $2.266^{\mathrm{e}}$ & 0.082 \\
\hline & $\mathrm{B}$ & 1.491 & 0.233 & 1.989 & 0.145 & 0.947 & 0.409 & 0.669 & 0.583 & $0.708^{\mathrm{e}}$ & 0.557 \\
\hline & $\mathrm{C}$ & $9.961^{\mathrm{c}}$ & $0.007 * *$ & 3.785 & 0.078 & 23.582 & $0.001 * *$ & 0.271 & 0.621 & 2.479 & 0.134 \\
\hline \multirow[t]{3}{*}{$\mathrm{OC}_{\min }\left(\% \mathrm{OC}_{\mathrm{UT}}\right)$} & A & 2.440 & $0.030^{*}$ & 2.305 & 0.082 & 1.080 & 0.353 & 1.299 & 0.294 & 1.937 & 0.126 \\
\hline & B & $1.147^{\mathrm{e}}$ & 0.391 & 1.063 & 0.409 & 1.254 & 0.314 & 0.585 & 0.634 & $6.966^{\mathrm{e}}$ & $0.002^{* *}$ \\
\hline & $\mathrm{C}$ & $0.167^{\mathrm{e}}$ & 0.977 & 0.061 & 0.979 & 0.072 & 0.932 & 0.489 & 0.510 & $0.162^{\mathrm{e}}$ & 0.853 \\
\hline
\end{tabular}

${ }^{a}$ Dfs are 10, 4, 2, 4 for model, vegetation lithology and interaction, respectively, in the case of the analysis of variance in A horizons; 9, 4, 2, 3 in $\mathrm{B}$ ones and 6, 3, 2, 1 in $\mathrm{C}$ ones.

${ }^{\mathrm{b}}$ Dfs are 4, 35, 39 among groups, within groups and total, respectively for A horizons; 3, 22, 25 for B horizons and 2, 10, 12 for $\mathrm{C}$ ones.

${ }^{\mathrm{c}}$ The variables were inverse transformed before the analysis

d The variables were LG10 transformed before the analysis

${ }^{\mathrm{e}}$ The variables were $\mathrm{LN}$ transformed before the analysis

${ }^{\mathrm{f}}$ The variables were square root transformed before the analysis 
Figure 1 - Study area and location of soil profiles.

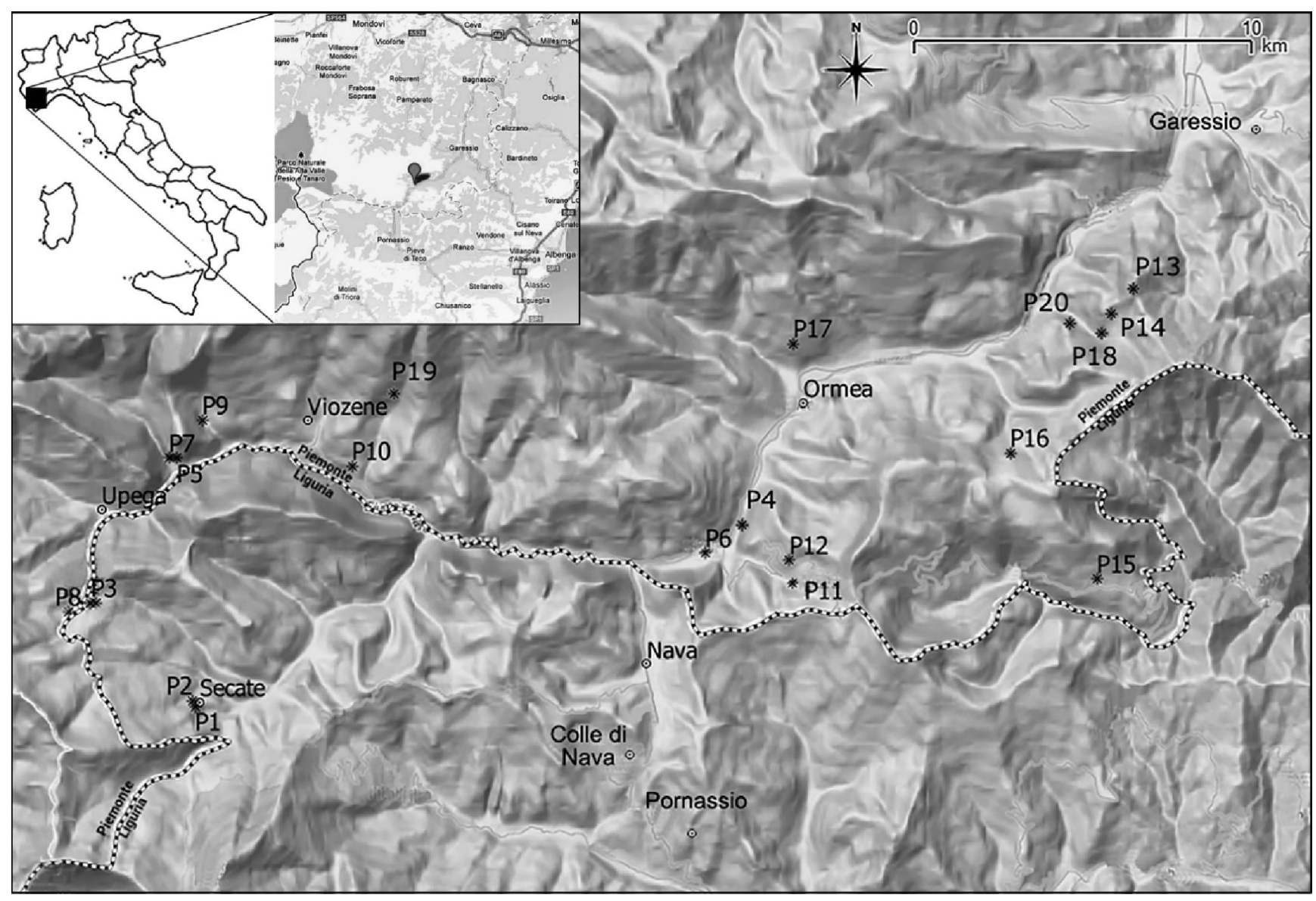


Figure 2 - Relationship between the total $\mathrm{OC}_{\mathrm{UT}}$ amounts and the amounts of a) $\mathrm{NaClO}$-labile $\left.\mathrm{OC}\left(\mathrm{OC}_{\mathrm{lab}}\right), \mathrm{b}\right)$ chemically recalcitrant $\mathrm{OC}\left(\mathrm{OC}_{\mathrm{rec}}\right)$ and $\left.\mathrm{c}\right)$ mineral-associated $\mathrm{OC}\left(\mathrm{OC}_{\min }\right)$.
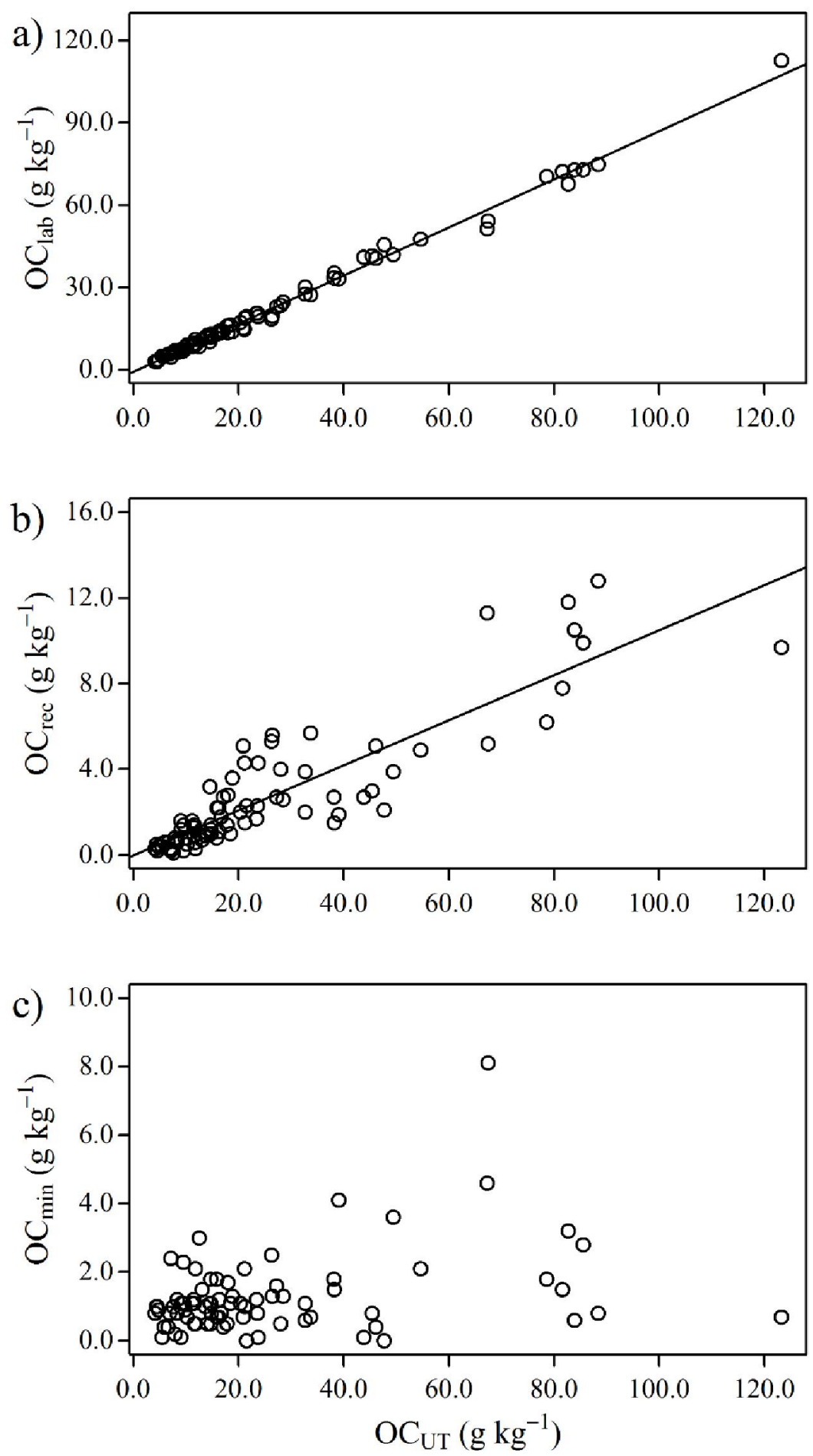
Figure 3 - Effect of soil and horizon type on a) NaClO-labile $\mathrm{OC}\left(\mathrm{OC}_{\min } \% \mathrm{OC}\right.$ UT $)$, b) chemically recalcitrant $\mathrm{OC}\left(\mathrm{OC}_{\mathrm{rec}} \% \mathrm{OC}\right.$ UT $)$ and c) mineral-associated $\mathrm{OC}\left(\mathrm{OC}_{\min } \% \mathrm{OC}_{\mathrm{UT}}\right)$. Letters represent significant $(P<0.05)$ differences (Duncan's test) among groups and bars represent the standard error.
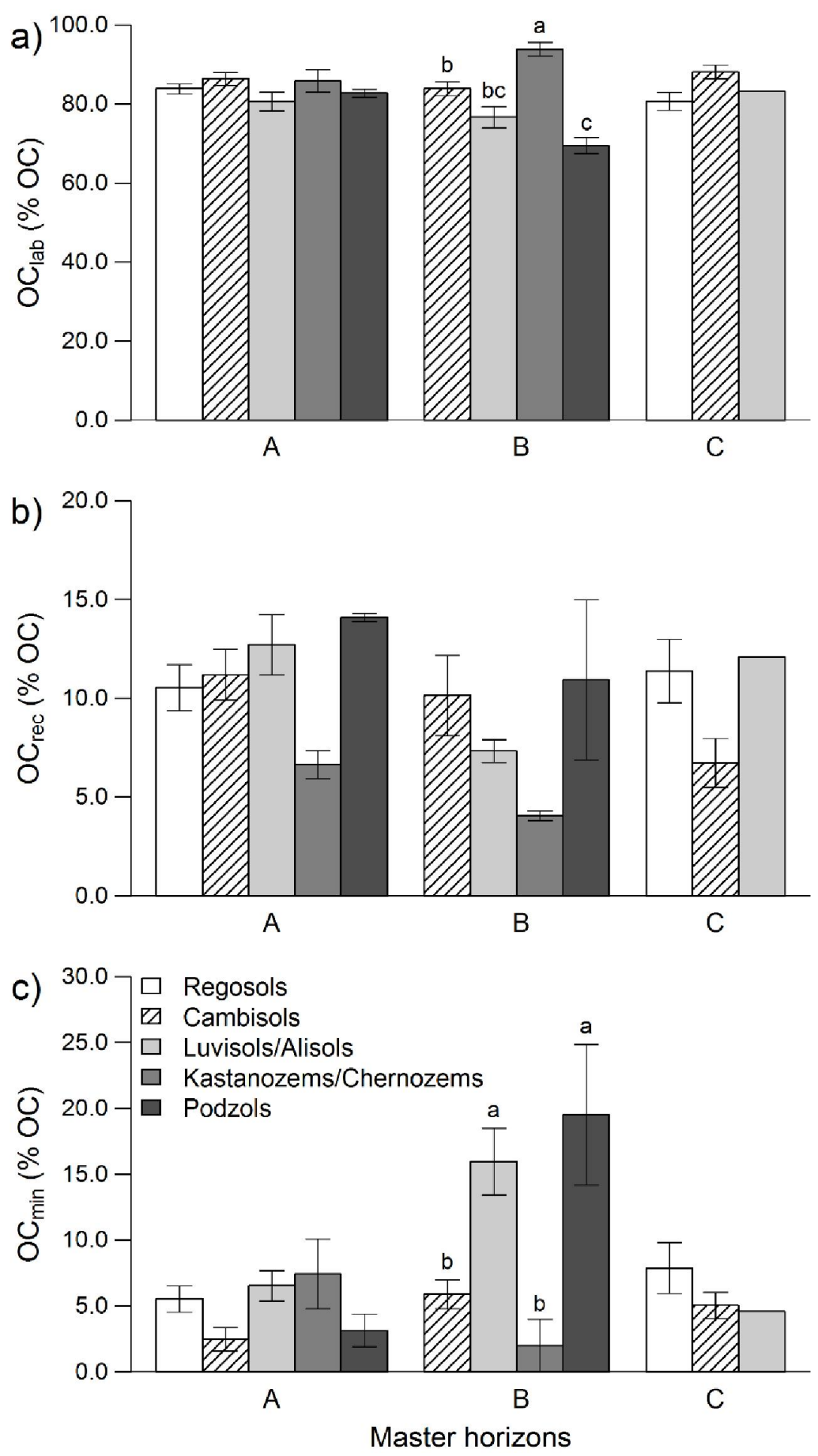


\section{$\underline{\text { Electronic annex }}$}

Effect of pedogenic processes and formation factors on organic matter stabilization in alpine forest soils

Journal name: Geoderma

Marcella Catoni*, Michele E. D’Amico, Ermanno Zanini, Eleonora Bonifacio

Department of Agricultural, Forest andFood Sciences (DISAFA), University of Torino, Largo Paolo Braccini 2, 10095

Grugliasco, Italy. *Corresponding author: Marcella Catoni, e-mail: marcella.catoni@unito.it

Table A1: Pearson's correlation coefficients between organic carbon concentrations in soil horizons and elevation and slope steepness.

\begin{tabular}{rrrrr}
\hline Horizon & Elevation & \multicolumn{3}{c}{ Slope steepness } \\
& $\boldsymbol{r}$ & $\boldsymbol{P}$ & $\boldsymbol{r}$ & $\boldsymbol{P}$ \\
\hline $\mathrm{A}$ & 0.126 & 0.437 & -0.349 & 0.075 \\
$\mathrm{~B}$ & -0.077 & 0.710 & 0.456 & 0.087 \\
$\mathrm{C}$ & 0.179 & 0.559 & 0.665 & 0.013 \\
\hline
\end{tabular}

Table A2: Soil type distribution with elevation and slope (data in parentheses are standard deviations).

\begin{tabular}{lcrr}
\hline Soil type & N & Elevation (m a.s.l.) & Slope steepness (\%) \\
\hline Regosols & 6 & $1191(282)$ & $67(11)$ \\
Cambisols & 6 & $1162(319)$ & $36(11)$ \\
Luvisols/Alisols & 4 & $1155(154)$ & $38(18)$ \\
Chernozems/Kastanozems & 2 & $1025(290)$ & $45(35)$ \\
Podzols & 2 & $1191(274)$ & $40(7)$ \\
\hline
\end{tabular}

